\title{
Decision-making for nature's contributions to people in the Cape Floristic Region: the role of values, rules and knowledge
}

\author{
Emmeline N. Topp ${ }^{1,2} \oplus$. Jacqueline Loos $^{1} \cdot$ Berta Martín-López ${ }^{3}$
}

Received: 11 March 2020 / Accepted: 4 December 2020 / Published online: 8 January 2021

(c) The Author(s) 2021

\begin{abstract}
Nature conservation on privately owned land depends on land managers' decision-making. Interactions between values, rules and knowledge ( $v r k$ underpin decision-making, thus, it is important to understand these interactions to support conservation intentions. We investigated how different sets of vrk determine the decision-making context regarding the management and conservation of renosterveld, a critically endangered ecosystem in the Cape Floristic Region, and how this relates to land managers' perceptions of nature's contributions to people (NCP). From interviews with thirty land managers, we identified nine value types, four rule types, three knowledge types and 13 different NCP. We found that different $v r k$ combinations can be grouped into three decision-making contexts: Bottom-up conservation, Top-down conservation and Utility. Each context is associated with the perception of different beneficial and detrimental NCP. Regulating NCP are perceived across all contexts, whereas more non-material NCP are associated with a Bottom-up conservation context and relational values, such as family ties. The prevalence of relational values in Bottom-up and Top-down conservation contexts illustrates the complexity and non-substitutability of the dynamic relationships between renosterveld and people. This indicates the importance of plural valuation in nature conservation to foster diverse NCP provided by renosterveld.
\end{abstract}

Keywords Ecosystem services · Local ecological knowledge $\cdot$ Private land conservation $\cdot$ Relational values $\cdot$ Renosterveld South Africa

\section{Introduction}

As is widely demonstrated by the evidence given by the global and regional assessments of biodiversity and ecosystem services in the last two decades, biodiversity and its ability to provide multiple nature's contributions to people (NCP) are increasingly threatened (IPBES 2018, 2019;

Handled by Shizuka Hashimoto, University of Tokyo, Japan

Emmeline N. Topp

emmeline.topp@leuphana.de

1 Institute of Ecology, Leuphana University Lüneburg, Universitätsallee 1, 21335 Lüneburg, Germany

2 Agroecology, Department of Crop Science, Georg-August University Göttingen, Grisebachstraße 6, 37077 Göttingen, Germany

3 Institute for Ethics and Transdisciplinary Sustainability Research, Leuphana University Lüneburg, Universitätsallee 1, 21335 Lüneburg, Germany
Millennium Ecosystem Assessment 2005; Díaz et al. 2019). NCP are defined as "all the contributions, both positive and negative, of living nature to people's quality of life" (Díaz et al. 2018, p 270) and encompass other conceptualizations of these contributions, such as ecosystem goods, services, benefits or nature's gifts (Díaz et al. 2018; IPBES 2019; Ellis et al. 2019). The recent Global and Regional Assessments of Biodiversity and Ecosystem Services of the Intergovernmental Science Policy Platform on Biodiversity and Ecosystem Services (IPBES) provide evidence on the essential role of both biodiversity and NCP for the good quality of life of human societies, and how both biodiversity and NCP are jeopardized by multiple drivers of change (IPBES $2018,2019)$. Among the full array of drivers of change, the transformation of ecosystems to agricultural and urban land is considered the largest driver undermining the capacity of biodiversity to provide NCP (Millennium Ecosystem Assessment 2005; Pereira et al. 2012; Díaz et al. 2019; IPBES 2018, 2019). However, land use changes result from the individual and collective decisions on land planning and 
management that are underpinned by the complex interactions between individual and societal values, rules and knowledge (IPBES 2019; Colloff et al. 2017b). These interactions form part of the institutions, governance structure and societal dynamics that are increasingly recognised as one of the most relevant knowledge gaps in ecosystem service research (Mastrangelo et al. 2019).

Interactions between values, rules and knowledge (vrk) define the decision-making contexts of individuals and social actors that drive actions either for conserving ecosystems or for transforming them to other land uses, such as agriculture (Martín-López and Montes 2015; Colloff et al. 2017a). The vrk perspective, which has originally been applied in climate change adaptation research (Wise et al. 2014; Gorddard et al. 2016; Prober et al. 2017), emphasizes that a particular actor uses a system of values, knowledge and rules when designing or deciding on ecosystem management actions. Reflection on these decision-making contexts can reveal pertinent aspects of how society and institutions shape decisions and enables identification of new options and strategies for conservation and ecosystem management (Colloff et al. 2018). In this paper, we refer to values $(\mathrm{V})$ as the importance of a particular asset (i.e. biodiversity and ecosystems) for itself or for others (Pascual et al. 2017). Diverse actors value biodiversity and ecosystems in multiple ways, including intrinsic, instrumental and relational values (Díaz et al. 2015; Chan et al. 2016; Pascual et al. 2017; Arias-Arévalo et al. 2018). While intrinsic values refer to the inherent value of nature as an end in itself, regardless of any human experience, instrumental and relational values are human-driven (Díaz et al. 2015). The valuation guidelines developed by IPBES acknowledges that intrinsic values are independent of human experience and therefore human valuation (Diaz et al. 2015); however, humans can express regard for biodiversity and ecosystems independent of human interest, reflecting subjective intrinsic values (O'Connor and Kenter 2019). While instrumental values refer to the value of nature for human utility, including economic benefits, relational values are those concerns related to the meaningfulness of relationships, such as those among people and between nature and people (e.g. people's sense of place, spirituality, social cohesion or responsibility towards biodiversity) (Chan et al. 2016; Pascual et al. 2017). Focusing on relational values among land managers in agricultural landscapes can help to foster stewardship values for conservation (Chapman et al. 2019).

Alongside values, rules and knowledge are important factors influencing decision-making. Rules $(\mathrm{R})$ refer to both 'rules-inuse', which include informal norms, practices, taboos, habits, and 'rules-in-form', which include legislation, treaties and directives (Gorddard et al. 2016). These rule types can be perceived and experienced at both the individual and collective levels (Paavola 2007; Ostrom 2009). Institutional diversity, including multiple formal and informal rules, enhances compliance, addresses conflicts and supports adaptive governance for natural resources (Dietz et al. 2008; Kenward et al. 2011; Emerson and Gerlak 2014). Knowledge (K) refers to the information, awareness, understanding and perspectives that have explanatory value for the issues being addressed (Colloff et al. 2018). Actors and institutions create, organize, transfer, share and use this knowledge (Cornell et al. 2013). Relevant knowledge for biodiversity conservation and land planning include scientific and technical knowledge, lay knowledge from practitioners, and local ecological knowledge (LEK) (Tengö et al. 2014; Colloff et al. 2018).

Interconnected $v r k$ sets can identify which elements must be employed, retained and used in order to achieve the desired outcome in decision-making (Gorddard et al. 2016). The vrk perspective therefore emphasizes that interactions between the systems of values, rules and knowledge held by a particular stakeholder group (e.g. land owners, environmental managers or national agencies) underpin current decision-making regarding conservation and land planning actions (Colloff et al. 2017a). These systems must be disentangled to better understand why land, particularly in areas of exceptional biodiversity, is often not managed for the intrinsic, instrumental and relational value of its biodiversity, and the related implications for the provision of NCP.

One such area is South Africa's Cape Floristic Region (CFR), a global biodiversity hotspot, which contains more than 9000 vascular plant species and is recognised as a Centre of Plant Diversity (Olson and Dinerstein 2002). More than $70 \%$ of natural vegetation in the CFR has been transformed to other land uses, primarily agriculture but also urbanization (Myers et al. 2000). Natural renosterveld vegetation has been particularly susceptible to transformation, due to its rich substrate and relatively accessible topography compared to other habitat types of the CFR (Topp and Loos 2019; Rouget et al. 2014). This transformation began in colonial times, although much occurred throughout the twentieth century (Newton and Knight 2005), and has led to major biodiversity losses which threaten the provision of NCP. In this landscape context, we thus aim to understand what interplay of values, knowledge and rules leads to specific land uses that result in certain NCP outcomes. To address this research goal, we specifically aim to: (a) unravel values, rules and knowledge that drive land use decision-making contexts by renosterveld land managers, and (b) identify which detrimental and beneficial NCP are derived from renosterveld subject to different decision-making contexts of land management.

\section{Case study}

Our study area is the Swartland municipality and its close surrounding in the Cape Floristic Region, South Africa (Fig. 1). This winter-rainfall region is situated approximately $60 \mathrm{~km}$ north of Cape Town and is well known for grain 
production, primarily wheat. The region's fertile soils and proximity to a major urban centre contributed to widespread transformation of land use from natural vegetation to intensive commercial agriculture (Newton and Knight 2005). The Swartland municipality covers an area of approximately $3707 \mathrm{~km}^{2}$. Land cover in the municipality is now mostly grain and legume cropland (approximately 63\% of total cropland), grazing land (27\%), and vineyards (6\%) (Western Cape AgriStats 2019). Urbanization has also increased rapidly in the Swartland over the last 40 years, with a current growth rate of 5.6\% (Western Cape Government 2017). This trend is partly due to an influx of migrant workers, as well as the expansion of the greater Cape Town metropolitan area into the southern part of the Swartland, and the expansion of the administrative centre Malmesbury (Halpern and Meadows 2013; Western Cape Government 2017). The endemic natural renosterveld vegetation has therefore been affected by both recent and historical land-use changes.

West-coast renosterveld, as part of the CFR, is globally significant in terms of biodiversity. It is a fire-prone, shrubscrub, evergreen ecosystem also known as 'Cape transitional small-leaved shrublands' (Cowling 1983). Renosterveld contains more than 800 plant species, including many endemic geophytes and succulents (Halpern and Meadows 2013; Bergh et al. 2014). Whereas renosterveld formerly covered much of the Swartland, less than 3\% natural west-coast renosterveld vegetation now remains, mostly in fragments on steep slopes and hilltops among intensively farmed private land (Moll and Bossi 1984; McDowell and Moll 1992; Newton and Knight 2005; Halpern and Meadows 2013). While agricultural expansion is the major driver of renosterveld loss in the Swartland, other threats include biological invasions and climate change, which can converge with poor land management and further deteriorate renosterveld (Kemper et al. 1999; Topp and Loos 2019). Regional scale conservation planning has taken place across the Cape lowlands (von Hase et al. 2003) and private easements are used as a conservation mechanism in south-coast renosterveld (Overberg Renosterveld Conservation Trust, www.orct.org), but conservation approaches remain piecemeal (Topp and Loos 2019). Some renosterveld fragments are designated municipal reserves on the outskirts of towns such as Malmesbury and Darling, but the majority are on privately owned land (Von Hase et al. 2010).

The Swartland landscape is therefore rich in contrasts, with remaining fragments of high biodiversity-value renosterveld largely surrounded by intensive, monocultural grain and fruit production. Such contrast creates a complex decision-making context for land-use planning, as biodiversity conservation implementation is often not a priority for farmers and those responsible for agricultural land-use decision-making (Topp and Loos 2019; Winter et al. 2007). In terms of values, previous studies have found farmers to perceive renosterveld as largely unprofitable and associate its retention with problem plants and animals, as well as lack of financial reward (McDowell et al. 1989; Von Hase et al. 2010; Winter et al. 2005, 2007). Meanwhile, formal rules including legislation exist to prevent ploughing of virgin soil (National Environmental Management Biodiversity Act of 2004), and renosterveld fragments are nationally designated as critical biodiversity areas. However, multiple barriers inhibit conservation action by land managers, including the lack of knowledge and awareness of importance of biodiversity, high cost of conservation measures and lack of institutional collaboration (Winter et al. 2007; Cowling et al. 2003; Musil et al. 2005;
Fig. 1 Map of study area and location of the Cape Floristic Region (CFR) in south-western South Africa (inset, CFR indicated in light grey). The Swartland municipality is outlined in grey. Remaining renosterveld fragments are visible in red. Urban centres are represented by black squares. Properties under management by sampled land managers with remaining renosterveld fragments $(n=30)$ are located within the Swartland municipality plus a $10 \mathrm{~km}$ buffer and are indicated by blue circles

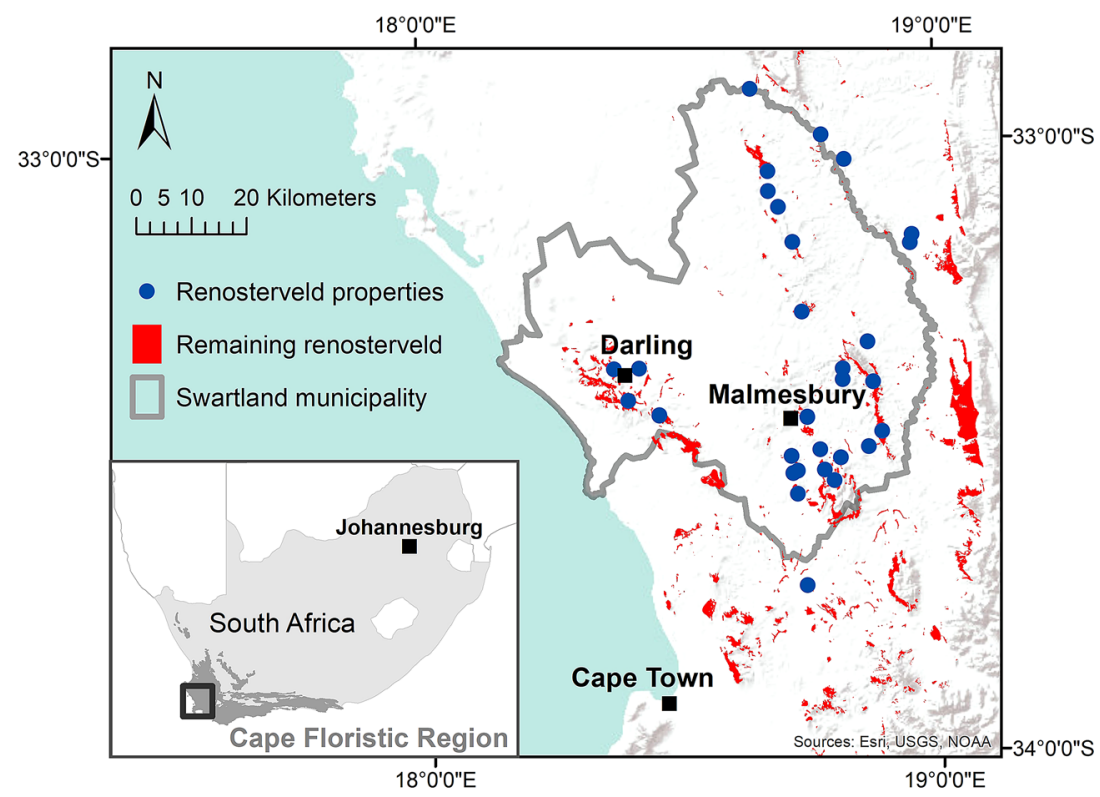


Topp and Loos 2019). The transformation of land management towards conservation management requires changes in values and aspirations, which may facilitate shifts in industry practice and rules such as government regulations (Pelling 2011; Prober et al. 2017). These barriers and values may differ among land managers with different farming systems (Darnhofer et al. 2005). With the application of the $v r k$ and NCP perspectives, we seek to unravel the complex decision-making contexts and implications for related NCP.

\section{Materials and methods}

\section{Sampling strategy}

Two fieldworkers conducted interviews with 30 land managers across the Swartland municipality with renosterveld remnants on their land (Fig. 1). As we wanted to explore differences between farming systems, interviewees were selected to account for both wheat $(W h)$ and wine grape (Wi) production as well as for differently-sized renosterveld fragments in the landscape. Fieldworkers conducted face-to-face semi-structured interviews in both English and Afrikaans between September 2017 and December 2018. A draft of the questions was piloted with colleagues and land managers and revised before fieldwork. We structured the interviews in three sections, including questions concerning: (1) General history and factual information on farming and land management; (2) Experiences with biodiversity and ecosystems, including wildlife encountered in renosterveld; (3) Perceptions of the benefits and detriments renosterveld provides. In this last section, we designed mostly open-ended questions to capture information on beneficial and detrimental NCP (e.g. "What are the benefits from nature on your farm?"; "What threats do you perceive?"), values related to renosterveld (e.g. "What is the renosterveld good for, for you and for society?"; "Why do you appreciate this place?"), the formal and informal rules underpinning land use (e.g. "How do you manage the renosterveld?"; "Do you get any help from external sources for farming or land management?") and land manager's knowledge (e.g. "What can you tell me about the renosterveld on your farm?"; "Why did you leave a patch of renosterveld on your farm?"). We used open-ended questions since they capture the perceptions of beneficial and detrimental NCP and plural values of biodiversity, ecosystems and NCP (Klain et al. 2014; Arias-Arévalo et al. 2017; Masterson et al. 2017; Tadaki et al. 2017; Jacobs et al. 2018). Socio-demographic data such as age, gender and land ownership type were collected in writing before the interview commenced. The duration of the interview varied between 17 and 50 min (see Appendix 1 for the interview details).

Interviews were recorded, transcribed and translated from Afrikaans to English in full. Before the interview, respondents were given information on the purpose and background of the research and gave written consent to their participation. Ethical clearance for the study was obtained through the University of Göttingen Ethics Commission on 15.11.2017.

\section{Content analysis}

We loaded interview transcripts into the text analysis software MaxQDA 2020 (Verbi Software 2019) and coded each interview according to two different frameworks: the vrk perspective (Colloff et al. 2017b; Gorddard et al. 2016) and the NCP paradigm (Díaz et al. 2018). The content analysis includes a reiterated review of the corpus made up by the transcripts of the 30 interviews. Through the content analysis, we identified the main categories of values, rules, knowledge and NCP types, and also captured newly emerging NCP categories.

To address the first specific objective, we applied the $v r k$ perspective (Colloff et al. 2017b; Gorddard et al. 2016) and coded for values, rules and knowledge. We coded for values by distinguishing between subjective intrinsic, instrumental and relational values (Chan et al. 2016; Pascual et al. 2017; AriasArévalo et al. 2018). Reference to the worth of nature for its own sake and the right of nature to exist was placed under the code of subjective intrinsic value, while reference to monetary benefits was coded as instrumental values (see Arias-Arévalo et al. 2017). We further identified multiple relational values, such as the meaningful relationships between people and nature that derive from sense of place, aesthetic enjoyment, leisure, interdependency with nature, family ties or moral duty to biodiversity (Table 1). We coded rules by classifying both (1) formal rules, including legislation, market arrangements and conservation agreements, and (2) informal rules, such as community practices, relations and habits (Table 2) (Abson et al. 2017; Prober et al. 2017). We coded the systems of knowledge by considering how land managers acquire knowledge. We considered three different types of knowledge acquisition: (1) LEK, including both local knowledge transmitted through cultural settings and regional history, and experiential knowledge relating to the acquisition of understanding through daily experiences and observation; (2) scientific knowledge, stemming from research sources and institutions; and (3) technical knowledge, related to farming practices and technologies (Table 3). In addition, we also noted when land managers expressed a lack of value of renosterveld, lack of rule enforcement and a lack of knowledge related to renosterveld.

To address the second research objective, we operationalized the classification of NCP (Díaz et al. 2018) by coding both detrimental and beneficial contributions of remaining renosterveld fragments to people. When coding, we distinguished between beneficial and detrimental NCP, as well as between material, non-material and regulating NCP (Table 4). As stated by Díaz et al. (2018), a particular NCP may be framed as beneficial or detrimental, depending on the social actors' cultural and socio-economic contexts (Saunders and 
Table 1 Values articulated by renosterveld land managers

\begin{tabular}{llll}
\hline Value type $\quad$ Articulated value & $n$ & $\begin{array}{l}\% \text { of all } \\
\text { verbatim } \\
\text { segments }^{\mathrm{a}}\end{array}$ & Example verbatim \\
& & \\
&
\end{tabular}

Instrumental Direct or indirect monetary benefit; utility $23 \quad 26.3$ cially, it will be ecotourism." (Wh1)

"At the moment I only make money from the paragliders and the Wifi towers on the mountain." (Wh5)

Subjective intrinsic Nature's right to exist

$15 \quad 9.0$

Relational

Sensing wildlife \& nature

$22 \quad 14.3$

Moral duty \& concern for nature

$21 \quad 15.5$

Family ties \& future generations

$15 \quad 9.5$

Interdependency of nature and farming

$21 \quad 9.5$

Recreation \& leisure

$15 \quad 7.2$

Aesthetics

$9 \quad 5.4$

Sense of place $\begin{array}{ll}7 & 3.3\end{array}$
"I think it must be a part of the farm. Because it is there, it is growing there and it must be there. I think we must leave it there because it's there for a reason." (Wi8)

"For us, the benefit of having a piece of veld is we go walking there throughout the year, and there's always something to see." $(\mathrm{O} 1)$

"It is our duty to protect the nature as a farmer. Because it is an ongoing relationship between nature and farming."(Wi7)

"I just feel that nature as it was made should be protected, we can't just let everything go.”(O2)

"I grew up with it... we used to go and pick the bulbs there and give them little names... we picked it with my grandmother....It's just a generation thing...I don't want it to become extinct." (Wi1)

"To preserve your land for the future generations or future farmers, you have to be careful with what you're doing." (Wh1)

"Farming is close to nature. So if you do not care about nature I don't think you will be successful in farming." (Wi10)

"These days there's a Funduro with quad bikes and stuff, so there's more of a relationship with recreation than farming. We don't use the mountain or the renosterveld for farming, but only to enjoy it." (Wh8)

"I think it is so nice for me to go for a walk there on Sundays. You can sit and drink your coffee or tea and the dogs play about in the veld... and have this peaceful experience there." (Wh13)

"In a different kind of way, it's beautiful. It's another beautiful than farming, you can sit up there and have a beer. It's really nice. Looking over the renosterveld." (Wi9)

"It makes quite a difference to go and walk in the veld than just to drive around in the car or tractor. There's millions of species and different plants and stuff. It's beautiful. I love it."(Wh11)

"Everybody knows that if you are situated in Malmesbury or the Swartland, it is recognizable by the renosterbos." (Wi4)

"It's what the society hinges on, it's really what it is, I mean the renosterveld is Darling." $(\mathrm{O} 3)$

$n$, number of interviews; Wh, wheat farmers; Wi, wine farmers; O, other management practices

${ }^{a}$ Verbatim segments that relate to values (i.e., not rules, knowledge or NCP)

Luck 2016; Díaz et al. 2018). In our study, we considered NCP to be detrimental when the interviewee framed the NCP has having a negative impact either to people or to ecological integrity of renosterveld. Thus, the same NCP can appear as a beneficial and detrimental contribution throughout the content analysis. Likewise, a particular NCP does not necessarily fit squarely into the categories of material, non-material and regulating and, therefore, in such cases, we classified the NCP in multiple categories. Additionally, the operationalization of NCP contains a mixture of general and context specific perspectives (see Díaz et al. 2018). We applied this by first following the generalizing perspective through assigning expressed NCP to general categories from the framework, and second, by using the information from farmers to identify new 


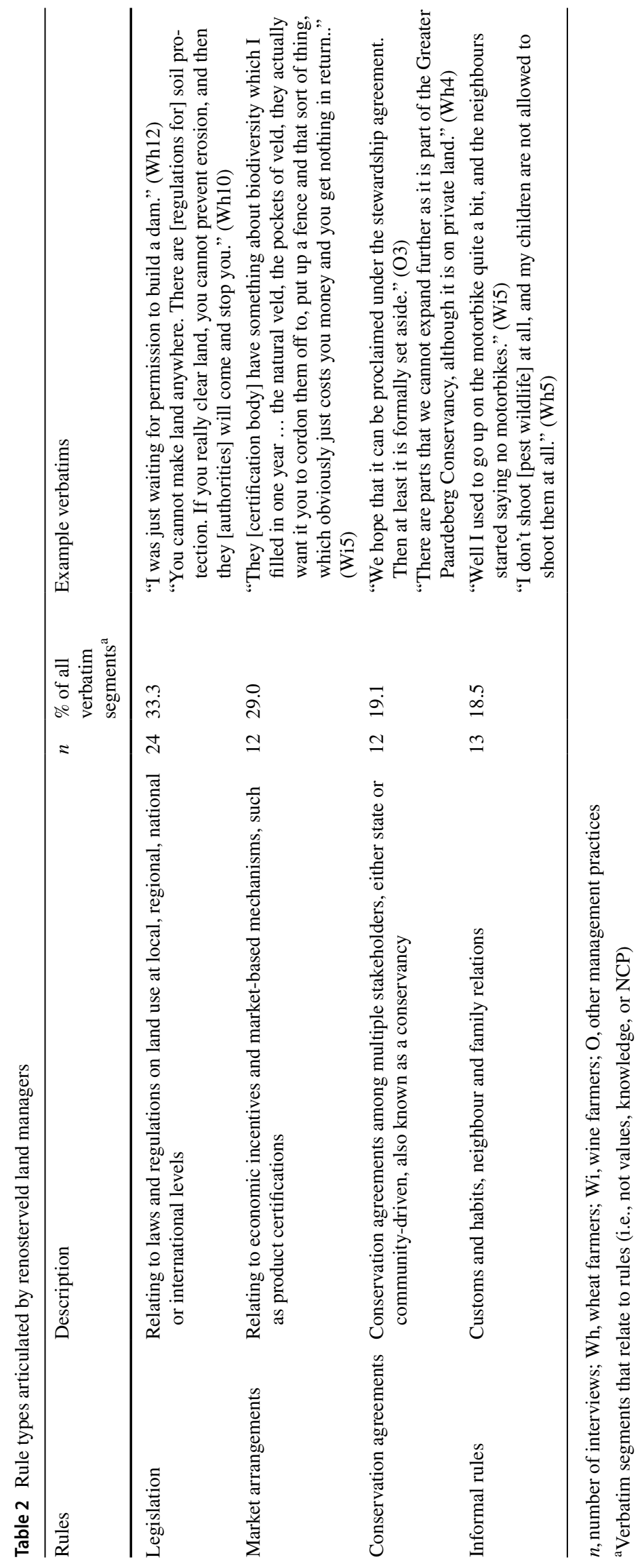




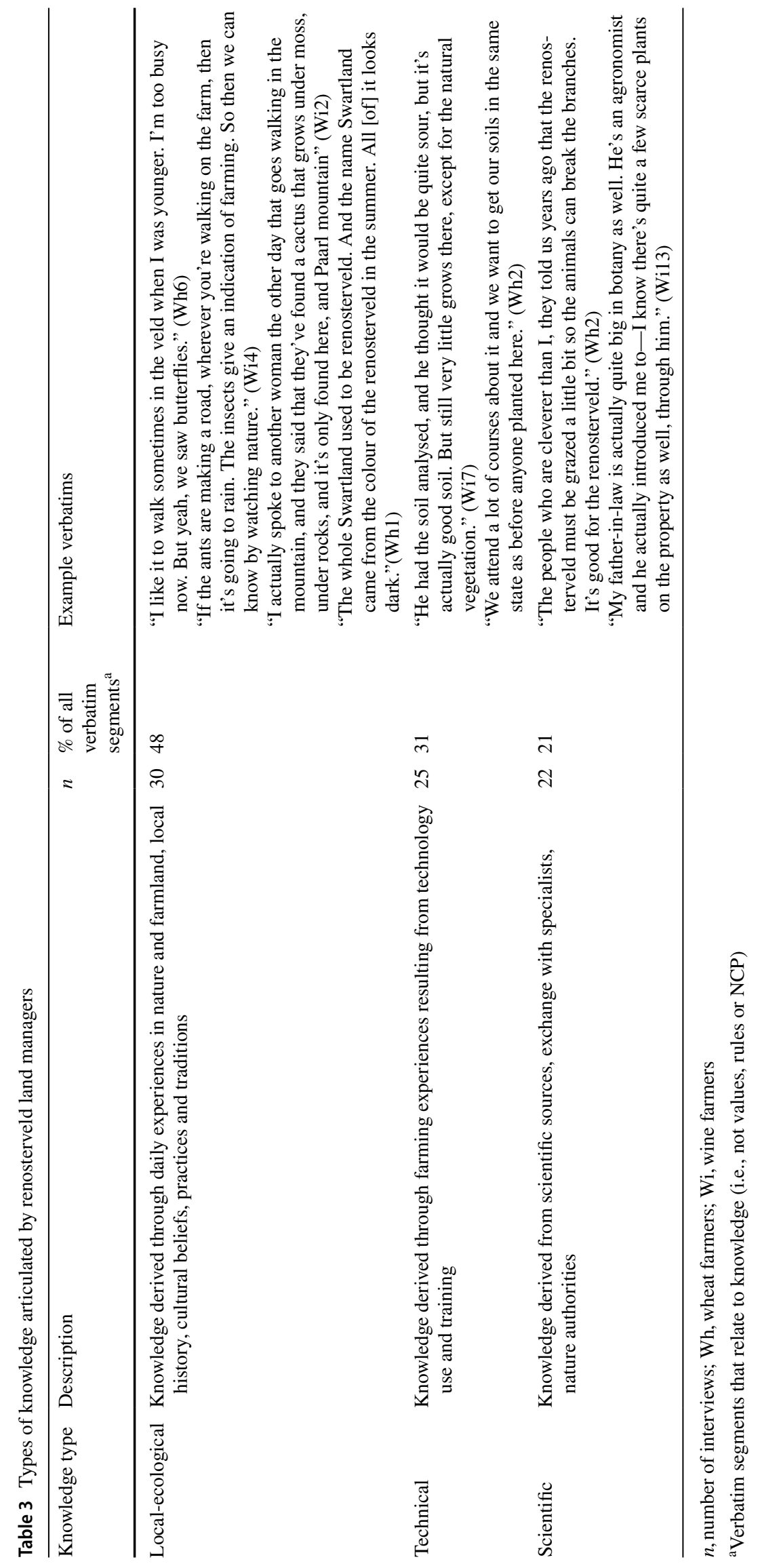




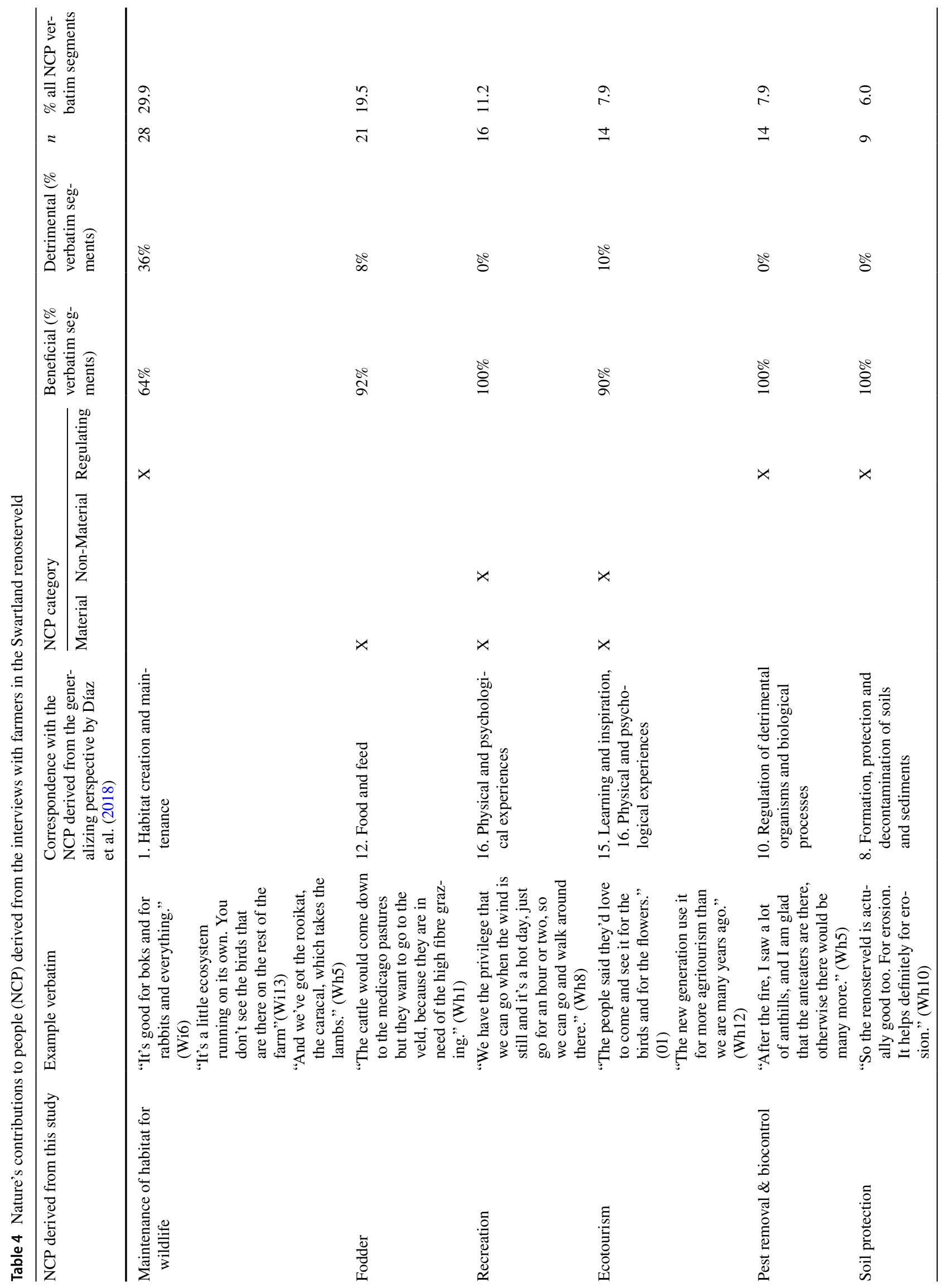




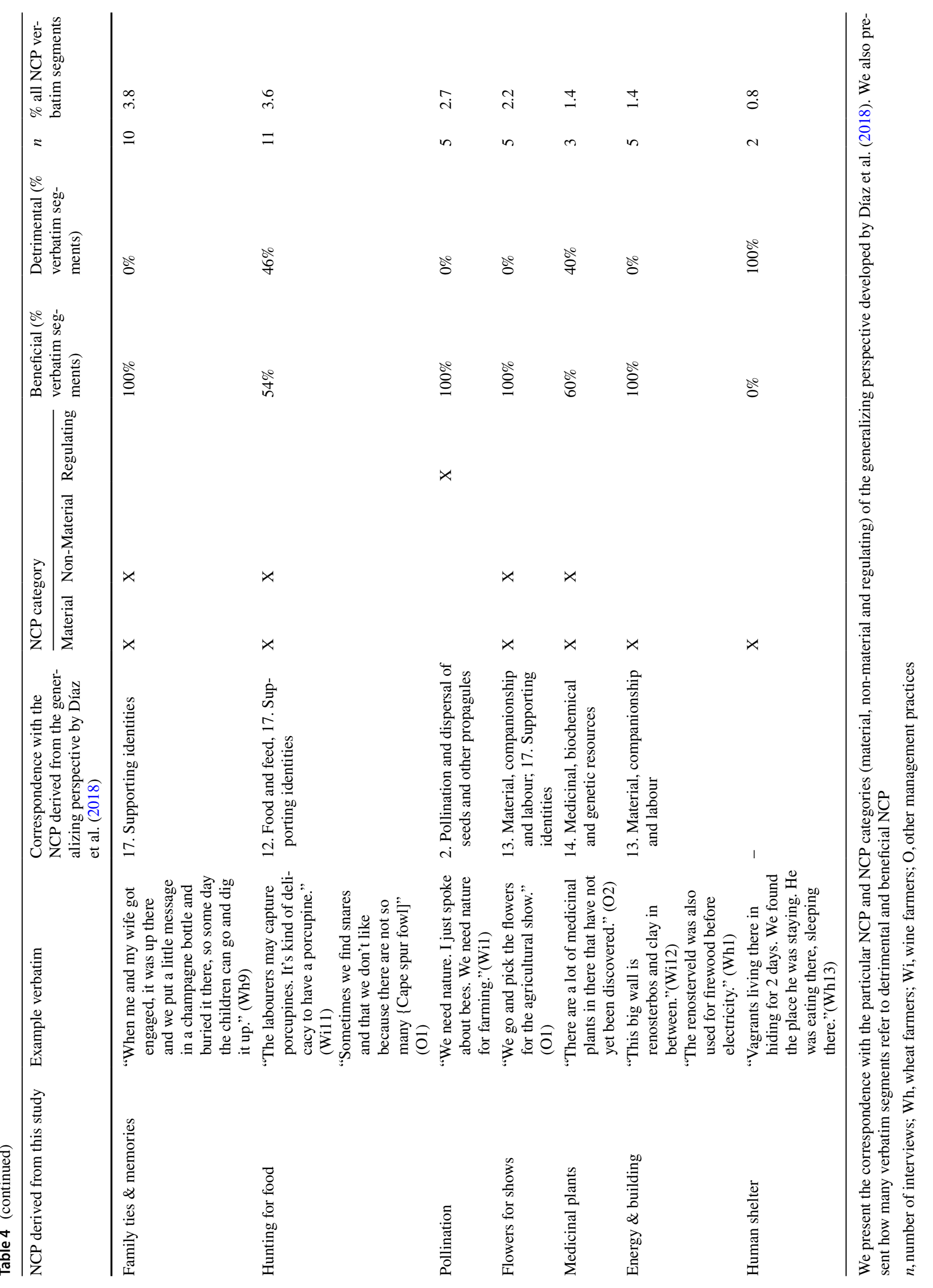


$\mathrm{NCP}$ which do not fit in the existing generalizing perspective, but are region and context-specific (Díaz et al. 2018). We included family ties as an NCP as well as a relational value, because family activity in renosterveld may be a tangible NCP, whereas the importance of preserving renosterveld for future generations is a relational value.

The results present the qualitative content analysis with example verbatims (the words of the interviewees, lightly edited for ease of reading without altering meaning) and descriptive analysis that shows differences between wheat and wine farmers. We explored whether the expressed $v r k$ and perceived NCP differed between wheat and wine farmers. We then pooled the coded $v r k$ from all land manager interviews and checked for associations among vrk components. In an exploratory first step, we created a pairwise matrix of $v r k$ based on proximity of codes within the interview text and mapped these vrk into a multidimensional ordination (see Appendix 2) to see if groupings of $v r k$ elements emerged from the data. The ordination is based on Principle Co-ordinates Analysis and is part of the Code Maps function provided in the text analysis software MaxQDA 2020 (Verbi Software 2019). In a second qualitative step, we used pairwise matrices to manually check for associations among $v r k$. In a third step, we generated frequency tables for vrk and NCP to see which NCP occurred with each vrk component (see Appendix 3). From this analysis we distinguished three separate decision-making contexts that are underpinned by a particular $v r k$ interplay and are related to different NCP. It is important to note that one NCP could be associated with more than one decision-making context.

The resulting contexts are not definitive, so each combination of elements does not automatically lead to the associated land management decision; rather, the decision may result from the associated combination of $v r k$ elements, based on our interpretations of the interviews with land managers.

\section{Results}

\section{Sample characteristics}

While most interviewees $(n=27)$ were actively farming their renosterveld-adjacent land, three were responsible for the renosterveld fragments, but not adjacent farming activities and were characterized as "Other management practices $(\mathrm{O})$ ". Of active farmers, 13 were primarily farming wheat and 14 were primarily farming wine grapes, although many farms $(n=24)$ contained a mix of these crop systems, plus other fruit, vegetables and livestock (sheep and cattle; see Appendix 1 for full interviewee data). The majority of interviewees were aged between 30 and $50(62 \%)$ and the majority identified as male (90\%). The main spoken language on sampled farms was Afrikaans, except for one farm where English and Xhosa were the main spoken languages. Farms ranged from 46 to 1800 hectares in size. The median farm size was 477 hectares. Renosterveld fragments ranged from 0.3 to 1401 hectares in size and the median fragment size was 13.9 hectares. The majority of land managers owned the farm in a family trust $(57 \%)$, while $23 \%$ were sole owners and $13 \%$ were employed by landowners.

\section{Values}

Relational values related to nature and renosterveld, including seven different articulated sub-types, were expressed by land managers more frequently than intrinsic and instrumental values (Table 1). Of relational values, the most frequently articulated value types were sensing wildlife and nature, moral concerns for nature, family ties to the landscape and interdependency of nature and farming (Table 1). We found little difference between the articulated values of wine and wheat farmers, particularly for subjective intrinsic and relational values (Fig. 2). However, we found that wheat farmers expressed more instrumental values related to nature than wine farmers (Fig. 2).

As well as expressing different value types related to nature and renosterveld, almost all land managers expressed that renosterveld lacks value $(n=27)$. This perception often related to the perceived lack of instrumental values and monetary benefits, for example:

"Up to now, I didn't think about anything about it, it's just wasted land. I had to pay for 470 hectares and that is 70 hectares I can't plant on, so for me it's a total loss." (Wh2); and "They don't bother with it [renosterveld], and they don't make any effort to know what's going on in there, because they can't make any money out of it." (Wh10).

One land manager expressed a widespread lack of valuing renosterveld while simultaneously acknowledging that this was regrettable, as illustrated by:

"Yes, it's so heart-breaking that in South Africa nobody is interested in fynbos. If this fynbos vanishes, then nobody will notice. Believe me. Nobody will notice it." (Wh6).

\section{Rules}

Formal legislation was the most frequently expressed rule type $(n=24)$ whereas informal rules were the least frequently expressed $(n=13)$ (Table 2$)$. Community conservation agreements differ from other formal conservation agreements in that they are more contingent upon community good will, compared to, for example, municipally owned and managed nature reserves or biodiversity conservation legislation. Biodiversity conservation legislation was not 


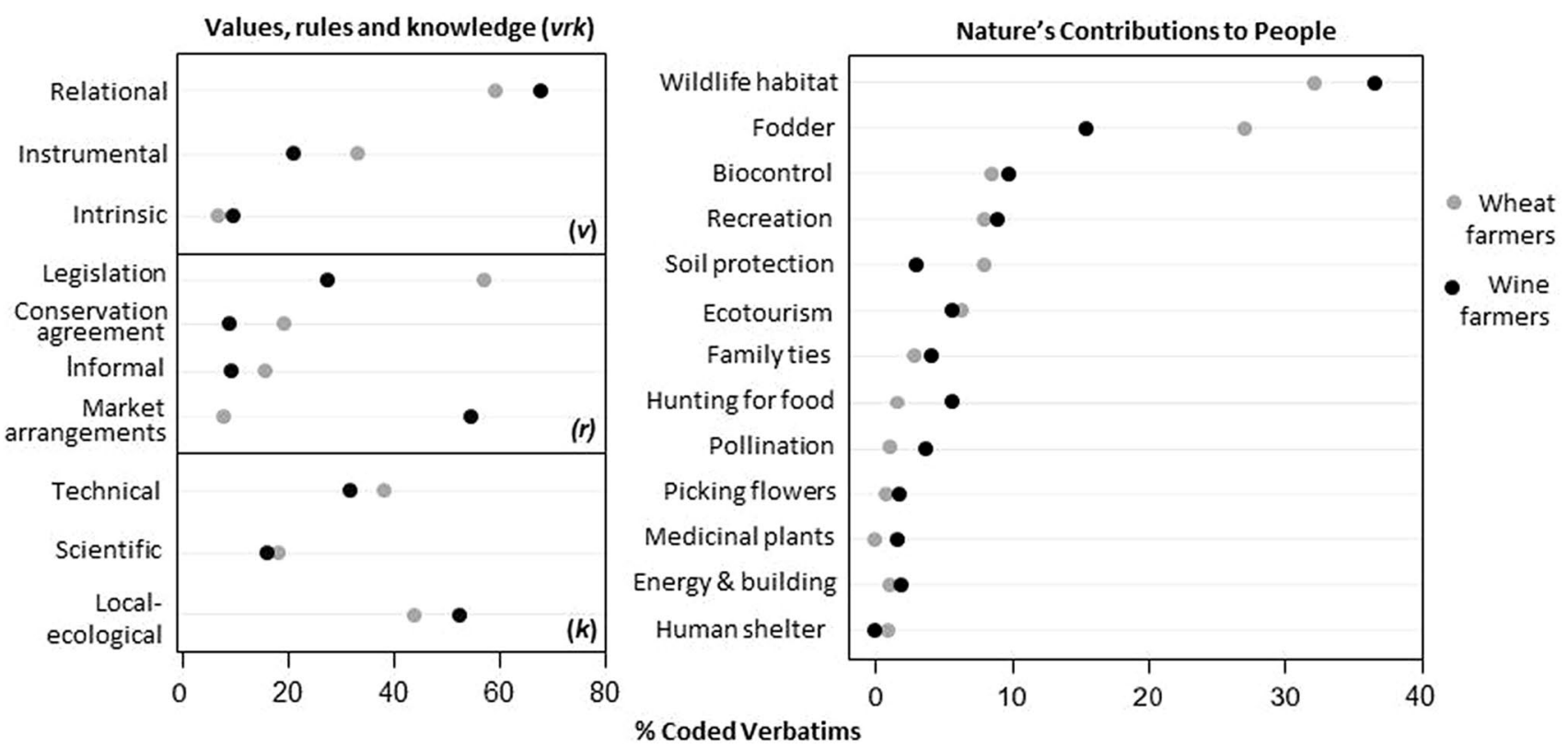

Fig. 2 Differences in the \% of coded verbatims between wine and wheat farmers ( $n=13, n=14$ respectively) for the expressed values, rules, knowledge and nature's contributions to people in the Swart-

explicitly named by land managers, although many were aware of such rules $(n=24)$. Perceived lack of rules relating to renosterveld and rule enforcement was expressed by 18 land managers, for example, regarding national legislation:

"I could take the renosterveld out and plant wheat, and I can assume no one in South Africa would stop me. I don't think there is any... I don't think it can be controlled." (Wh2); and "No reprimand or repercussions, nothing. It's rather that everyone keeps to his own business." (Wi3).

This could also result in conflict over renosterveld management, as illustrated by the next verbatim:

"Most people think that the renosterveld is public property. Whereas this specific [piece] is part of four farms. Even the local tourism board, they made three hiking trails with no control." (Wh5).

Land managers also mentioned informal rules as underpinning their decision-making $(n=13)$. In some cases, neighbour relations or family traditions influenced the way land managers chose to use their land. For example, one land manager explained the informal rules for keeping renosterveld flowers on a small hilly outcrop of renosterveld (known as a 'koppie'):

"In this case the farmers' mother was very much into flowers and the flower shows. She said to him, you don't do anything to this koppie! I mean he's come up land of South Africa's Western Cape. The x-axis represents the proportion of coded verbatims per $v r k$ component per farming group and from total of NCP

close, but he's leaving the koppie because his mother said to him - Leave the koppie." (O1).

There were differences in the way wheat and wine farmers perceived the role of rules (Fig. 2). While formal legislation was expressed more frequently by wheat farmers $(59.2 \%$ of verbatim segments) than wine farmers (26.9\%), market arrangement rules related to environmental issues were mentioned more frequently by wine farmers (53.8\%) than wheat farmers (6.1\%) (Fig. 2).

\section{Knowledge}

Land managers articulated diverse forms of knowledge. The most commonly expressed knowledge type was localecological knowledge ( $48 \%$ of verbatim segments), followed by technical knowledge (31\%) and scientific knowledge (21\%; Table 3). Scientific knowledge was often identified as belonging to other sources, such as scientists or researchers, whereas technical knowledge and LEK were more frequently expressed as belonging to the land managers themselves. LEK included substantial awareness of renosterveld-associated fauna derived from land manager observations, often mammals, for example:

"Well there are lots of jackals, and rooikat [caracal]. I've seen some rabbits through [the renosterveld]. Guinea fowl, lots of snakes, tortoises, lots of them. And then game, a few game species. Duikers, there's 
a few bush boks, and quite a bit of deer, I've seen." (Wh11).

However, many land managers $(n=24)$ expressed a perceived lack of knowledge on renosterveld ecology, and a corresponding lack of understanding of the ecological significance of renosterveld, as illustrated by the next verbatim:

"But you want to ask me about the renosterveld, you are asking the wrong guy. I'm not a plant guy at all." And: "For me it was just bushes, but for them [visiting botanists] it was something like gold." (Wh5).

This lack of knowledge of renosterveld ecology was related to a lack of renosterveld conservation rule enforcement. For example, one land manager described the difficulty with prevention of unregulated harvesting of medicinal plants:

“Our law enforcement guys, they don't know the plants, so it's difficult to identify them if you just have the bulb. If you don't catch them red-handed, you can't do anything about it." (O3)

Knowledge types articulated by wheat and wine farmers were similar. Wine farmers expressed marginally more localecological knowledge $(52.4 \%)$ than wheat farmers $(43.9 \%)$, and wheat farmers marginally more technical knowledge (38.1\%) than wine farmers (31.7\%; Fig. 2).

\section{Nature's contributions to people}

Land managers articulated a range of NCP from both renosterveld and nature within the wider farming landscape (Table 4). The most frequently articulated NCP derived from renosterveld and nature in general was the maintenance of habitat for wildlife $(n=28)$. The verbatims show that a particular NCP can be simultaneously articulated by interviewees as material and non-material (Table 4). For example, renosterveld flowers are a material NCP, and picking them for display at regional flower and agricultural shows is also non-material in the sense that it is tied to local identity and family traditions:

"My grandmother used to do the agricultural show, where they had a big flower display area. We used to go and pick the bulbs there and give them little names. I can still remember it because we had to help her.'(Wi1).

In addition, interviewees articulated particular NCP as both beneficial and detrimental (Table 4). For example, ecotourism is considered as beneficial by creating positive experiences and for added farm income, but detrimental when it becomes difficult to manage, as illustrated by the next verbatim:
"When you develop it, then it is open to humans, and then you have got other challenges, like litter. They've got their demands, they want to have fire places and whatever." (Wh1)

While human shelter may be considered beneficial for the humans using the renosterveld as refuge, land managers considered it as detrimental due to fears of crime and damage to their land $(n=2)$. The contribution of renosterveld as human shelter led one land manager to consider removing remaining renosterveld:

"If you look at the bossieveld [renosterveld], one can easily hide there for a week or two and nobody will know about it. That is the biggest reason for me to change the renosterveld." (Wh13).

Wildlife habitat was often identified as a detrimental NCP by land managers $(n=18)$ due to the presence of pest wildlife, such as steenbok (Raphicerus campestris), caracal (Caracal caracal) and baboons (Papio ursinus). Alongside particular dominant shrubs (such as Galenia africana), which degrade productive farmland, these mammalian species were reported to threaten crops, livestock and people:

"Six years ago when we started planting very many grapes, we had big problems with the steenbok and the duikers, because they were eating up all our young grapes."(Wi9).

However, wildlife habitat was more often expressed as a beneficial NCP $(n=28)$, as illustrated by the next verbatims:

"It's good for boks and for rabbits and everything." (Wi6) and: "You get the wildlife in there, the tortoises, the antelope, the boks, steenbokkies and the duikers... obviously for the caracal as well, it's their habitat, where they thrive. You also find a load of flowers up there, especially in Springtime." (Wi2).

Some NCP were identified as beneficial to certain stakeholders, yet associated with negative impacts through potential for over-extraction. Thus, while the NCP itself is not detrimental to people, it may be regarded as incompatible with biodiversity conservation. For example, three interviewees reported medicinal plants as beneficial NCP for people's quality of life because of their contribution to health and cultural significance, but harmful for renosterveld integrity due to potential over-harvesting of plant species:

"The other thing that's a problem are the people harvesting medicinal plants. People have been seen going in there with spades coming back with bags of stuff, there's a whole lot of plants just taken out." (O2).

Similarly, fodder was described by interviewees as beneficial, due to the economic benefits of saving feed costs 
for livestock, but also detrimental for renosterveld through potential overgrazing by hardy native livestock breeds:

"The tough breed of sheep and the Nguni cattle are going to destroy these patches, definitely." (Wh6)

Perceptions of NCP provided by renosterveld were relatively similar between wheat and wine farmers (Fig. 2). We found the greatest difference between wheat and wine farmers for the NCP of fodder, which was expressed more by wheat farmers (27\% of verbatim segments) than by wine farmers (15.4\%) (Fig. 2).

\section{vrk-NCP decision-making contexts}

Our qualitative analysis identified three different groups of vrk associations. We considered each group as a distinct decision-making context for renosterveld land management and termed them: (1) Bottom-up conservation; (2) Top-down conservation and (3) Utility (Fig. 3). Each context consists of a combination of specific values, rules and knowledge, which is associated in turn with different bundles of NCP. The first decision-making context 'Bottom-up conservation' comprises of specific relational values (such as aesthetics and family ties), informal rules and LEK. The renosterveldderived NCP associated with this context included regulating, material and non-material NCP, such as maintenance of habitat for wildlife, fodder, hunting for food, flowers and family ties and memories. We termed this context "Bottomup conservation" with recognition that bottom-up conservation strategies are underpinned by community structures, local identities and cultural relations between people and ecosystems (Abrams et al. 2009).

The second decision-making context 'Top-down conservation' is comprised of intrinsic, instrumental and relational values (such as moral duty and concern for nature), formal conservation agreements, and scientific knowledge. We found that the outcome in terms of NCP, as perceived by interviewees, was similar to 'Bottom-up conservation', but lacks non-material NCP, such as preservation of family ties and memories and hunting for food. We termed this context 'Top-down conservation' in recognition that top-down approaches are driven by national and international government, large-scale NGOs and policy intervention (Abrams et al. 2009), and are rooted in scientific evidence (Lochner et al. 2003).

The third decision-making context 'Utility' focused on use of renosterveld as part of farming practices, primarily for grazing purposes. This context is underpinned by the interplay of instrumental values, formal rules, and technical knowledge. The outcomes perceived in terms of NCP included material, non-material and regulating NCP, such as fodder, soil protection, recreation and ecotourism. The Utility and Top-down conservation contexts included the regulating NCP pollination, and therefore contained more regulating $\mathrm{NCP}(n=4)$ than the Bottom-up conservation context $(n=3)$.

\section{Discussion}

Our analysis found that, in the context of renosterveld, certain vrk types were more likely to occur together, creating unique decision-making contexts that were associated with different sets of NCP. We discuss here first, the identified $v r k$ types and their interplays leading to different decision-making contexts; second, the findings and prospects for linking vrk and NCP; third, the limitations of our study and acknowledging dual perceptions of beneficial and detrimental NCP; and fourth, implications for future NCP assessments.

\section{vrk interplays and decision-making contexts}

The unique combinations of $v r k$ illustrate the aspects of societal decision-making, which can constrain or enable behavioural change (Colloff et al. 2017b). In our study, land managers articulated value statements that contained multiple, sometimes contrasting or conflicting values, often relating to production and conservation, as found elsewhere (e.g. Prober et al. 2017). For example, Wh4 expressed relational values including interdependency with nature for farming and aesthetic appreciation of renosterveld, while also expressing a lack of instrumental value of natural areas. The fact that relational values were expressed more frequently than instrumental and subjective intrinsic values illustrates the complexity, specificity and non-substitutability of relationships between renosterveld and people (Arias-Arévalo et al. 2017; Himes and Muraca 2018). Relational values are "demonstrated and solidified through behaviours associated with biodiversity conservation" (Allen et al. 2018, p 1). It is therefore important to speak to all values to promote native vegetation management by farmers (Gosling and Williams 2010; Chapman et al 2019). We found that in the Bottom-up conservation and Top-down conservation contexts, relational values were associated with LEK and scientific knowledge, combinations which can contribute to conservation mindsets and pro-environmental behaviour (Gosling and Williams 2010; Keniger et al. 2013; Soga and Gaston 2016; Ives et al. 2018). The overall prevalence of relational values, particularly sense of place and interdependency with nature, indicates the rich ongoing interactions between people and biodiversity in the CFR and the potential for care and stewardship action to result (Masterson et al. 2017; Jax et al. 2018; West et al. 2018).

Farming land managers expressed the contrasting belief that responsibility for conservation falls on state government, while land managers themselves preserve autonomy 


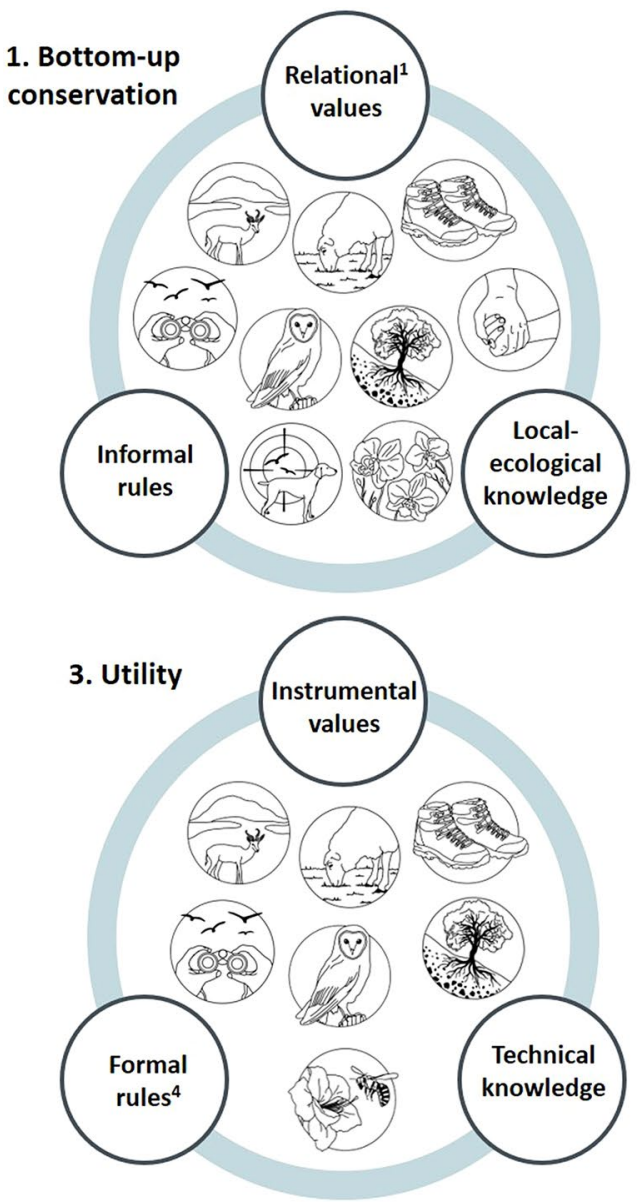

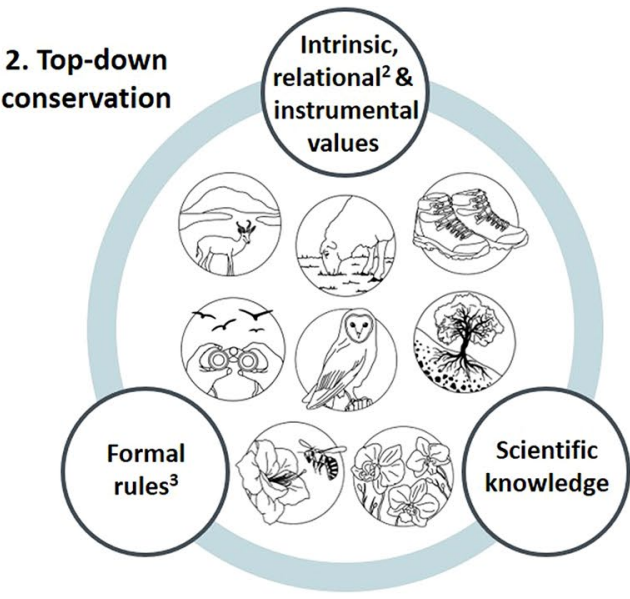

Key to Contexts

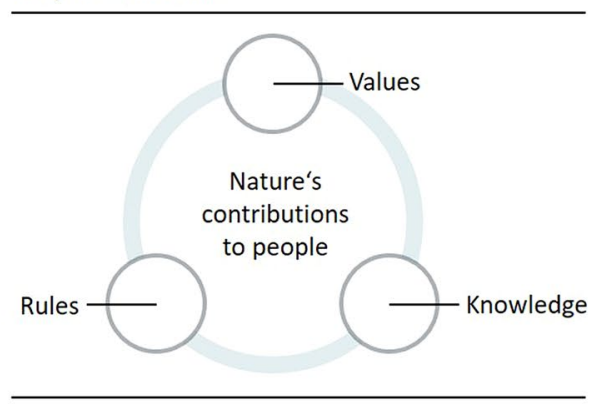

Key to NCP
Maintenance of
habitat for wildlife
Fodder
Recreation
Peotourism removal and
biocontrol
Soil protection
Family ties and
memories
Hunting for food
Picking flowers
Pollination

Fig. 3 vrk decision-making contexts: 1. Bottom-up conservation, 2. Top-down conservation and 3. Utility, showing combinations of values, rules and knowledge and associated NCP (illustrated in Key to Contexts). Icons representing different types of NCP are based on those from The Economics of Ecosystems and Biodiversity (TEEB) project (Sukhdev et al. 2010). ${ }^{1}$ Relational values include sensing

on land management decisions. In South Africa, state legislation relevant to renosterveld conservation includes the National Environmental Management Act and the Conservation of Agricultural Resources Act, which control the conversion of natural land, specifying virgin soil as land which has not been cultivated in the previous ten years (Conservation of Agricultural Resources Act 43 of 1983 1983; National Environmental Management: Biodiversity Act 10 of 2004 2013). However, land managers frequently expressed a lack of legislation enforcement, suggesting that other rule types play a role for renosterveld management. Indeed, we found that in the Utility context, market-based arrangements also provide limited incentive for renosterveld conservation activities. These arrangements consist of international audited production standards which require environmentally-friendly farming practices. However, these standards are applicable only to wine and table grape farmers, who export internationally, and not for wheat farmers who wildlife and nature, family ties, recreation and aesthetics. ${ }^{2}$ Relational values include moral duty and concern for nature and interdependency with nature. ${ }^{3}$ Specifically conservation agreements. ${ }^{4}$ Including market arrangements and legislation. For NCP categories see Table 4. For the statistical associations that led to vrk decision-making contexts, see Appendix 2 and 3

supply mainly to the domestic market. Such arrangements were reported to also lack strict enforcement and are not tailored to specific renosterveld conservation needs. Gorddard et al. (2016) note that the efficacy of formal or 'in-form' rules may be constrained or enhanced by informal or 'in-use' rules. For example, a plurality of rule types may limit rule avoidance (Dietz et al. 2008). Despite the plurality of rule types present in the Utility context, some land managers suggested that increasing reliance on this context could pose a threat to renosterveld integrity. For example, choosing to utilize renosterveld for livestock grazing could result in damage to renosterveld plant diversity. The Bottom-up conservation context contained only informal rules deriving from neighbourly and family relations, which combined with relational values. Such informal arrangements have been found to be more efficient conservation strategies than formal agreements in the Cape Lowlands (Von Hase et al. 2010). 
The lack of formal rule enforcement expressed by land managers was also linked to a lack of knowledge pertaining to renosterveld ecology and management and perceived lack of value, a result consistent with those found in an Australian land-use decision-making context (Prober et al. 2017). Here, as in other applications of $v r k$ to endangered species conservation, the $v r k$ perspective can help to identify limitations for decisionmaking options resulting from interactions among knowledge and rules (Colloff et al. 2018). For example, detailed scientific knowledge of renosterveld ecology is highly specialized and relatively difficult to acquire. Enforcing conservation legislation to regulate activities such as medicinal plant harvesting is hindered by the lack of scientific knowledge of law enforcers, who may not be able to identify plants. Additionally, land managers expressed a lack of scientific knowledge. These land managers may refrain from implementing conservation practices with the expectation that other actors with access to scientific knowledge, such as the state or nature conservation bodies, take responsibility for renosterveld conservation. For successful integration into decision-making, such knowledge must be perceived as legitimate, meaning it has been produced with respect to stakeholders' values, and with fair treatment of opposing interests (Cash et al. 2003). The plurality of values in the Top-down conservation context suggests potential for perceived legitimacy and thereby scope for further integration of scientific knowledge into renosterveld land management. However, land managers were found to have extensive LEK, which is particularly important as a means to foster NCP (Hill et al. 2019). The promotion of diverse knowledge types, for example, by combining LEK with scientific knowledge, is known to support effective land management and conservation of natural landscapes and NCP (Tengö et al. 2014, 2017; Morales-Reyes et al. 2019).

\section{Linking vrk and NCP}

We show that it is possible to link the $v r k$ perspective to NCP. The congruence of these frameworks rests on the inclusion of plural valuation, a fundamental part of the IPBES approach, as well as the importance of involving different knowledge types (Pascual et al. 2017). We concretize these concepts in our application of the two frameworks to the study region. We find that renosterveld fragments are multifunctional sources of NCP within the Swartland agricultural landscape and unique NCP bundles are associated with different decision-making contexts. The Bottom-up conservation context was associated with the NCP family ties and memories, flowers for shows and hunting for food, which link to local cultural traditions. These $\mathrm{NCP}$ can thus be viewed as non-material NCP and according to the IPBES framework, categorized as 'Supporting identities' (IPBES framework generalizing category \#17, Díaz et al. 2018). The multiple non-material NCP identified in our study may exemplify the relational value sense of place, which while not exclusive to a specific context, is a value known to strengthen protective norms and support environmental stewardship (Masterson et al. 2017). Regulating NCP (habitat for wildlife, soil protection and biocontrol) was associated with every context, contributing to recent evidence that stakeholders frequently identify not only tangible but intangible NCP in rural landscapes (Martín-López et al. 2012; Iniesta-Arandia et al. 2014). Renosterveld has been shown to be important for the regulating NCP hydrological function and soil protection (O'Farrell et al. 2009), and is here shown to be subjectively valued for additional regulating NCP, such as pollination and habitat for wildlife.

The identification of the different $v r k$ contexts may reveal how and why existing land management decisions might be perpetuated or constrained throughout the decision process (Gorddard et al, 2016). The vrk-NCP associations imply that should certain $v r k$ components be excluded from the decisionmaking context, renosterveld may not be managed optimally for certain NCP. For example, in the case that LEK and informal rules are excluded, NCP such as hunting for food and picking flowers for agricultural shows may be overlooked. Similarly, a reliance on a Top-down conservation context may miss the benefit of family ties and memories, which is associated with a Bottom-up conservation context. Renosterveld conservation activities, such as invasive species removal, appropriate burn regimes, livestock control, fencing of particularly rare or endangered species and awareness-raising of biodiversity, require multiple actors for implementation and diverse knowledge types. The implementation of these activities can be informed by reframing the decision-making context and supported by shifting societal values (Prober et al, 2017). Our study suggests that the multiple underlying relational values may be emphasised in such a reframing. Supporting bottom-up conservation approaches in particular diversifies management options, in which public agencies can remain pivotal enablers within a collaborative approach to conservation (Enqvist et al. 2019). Such work requires collective decision-making on behalf of land managers at the regional scale, particularly for larger fragments, which border multiple farms or constitute municipal reserves and may play important roles for ecological and social connectivity (De Vos and Cumming 2019). Thus, to foster widespread renosterveld conservation on privately owned land, recognition of all vrk components will be necessary in future decision-making.

\section{Study limitations and acknowledging dual perceptions}

Effective land planning is required to integrate not only agricultural land use with biodiversity conservation, but also social justice (Crane 2006; Hornby et al. 2018). Our study focused on land-use decision-makers and therefore does not represent every member of the Swartland society, including 
farm labourers, who are among those affected most by structural inequality. Given the land manager demographics, our study partially represents the voices of women. Considering Baker et al. (2019), we recognise that the positions of both researchers and subjects in our study contain implicit biases and power imbalances, stemming from the legacies of colonialism and apartheid and exacerbated by modern economic conditions. Our findings are thus only a part of a much wider narrative. This bias is inherent in the recognition of the NCP human shelter, which demonstrates the role that ecological systems play in regional societal complexity. Viewed from the perspective of the land manager, use of natural areas for human shelter is a detrimental NCP, whereas from the perspective of those requiring shelter, it may be viewed as beneficial. These divergent perspectives are echoed in other identified NCP, such as habitat for renosterveld wildlife. Acknowledging dual perceptions helps to address socialecological complexity, to recognise that as the same NCP may be viewed differently by different stakeholders, landscape management may include trade-offs (Saunders and Luck 2016; Saunders et al. 2016; Morales-Reyes et al. 2019; Pascual Rico et al. 2020).

Acknowledging nuances in perceptions of wildlife is another key part of embracing value and knowledge diversity into land management decision-making. While plant species diversity and endemism form the principal scientific basis for renosterveld conservation, we found, similar to Winter et al (2007), that a major relation between renosterveld and land managers is often mammalian wildlife (Sect. 4.5). The perception of this wildlife as pests leads to negative perceptions of renosterveld, although these fragments act as species refuges in the agricultural landscape and are vital for conserving the mammal assemblage of the CFR (Clements et al. 2019). Mammals are also hunted for food by farm labourers, an NCP which can be seen as beneficial from the perspective of the hunters but it was also perceived as a detrimental NCP by land managers (see Table 4). Such nuance must be taken into account when anticipating actions from land managers for control of wildlife on farmland (Morales-Reyes et al. 2018) and may help anticipate challenges to progress towards biodiversity-friendly farming landscapes in the CFR (Giliomee 2006).

\section{Implications for future vrk and NCP assessments}

Our study highlights that decision-making of agroecosystem management is characterized by interlinked configurations of values, rules and knowledge. We posit that future applications of the $v r k$ framework would find similar associations and interplays among vrk components, as we found (e.g. Prober et al. 2017). Regarding NCP assessment, the contextspecific approach we employed widens the scope of what constitutes NCP and illustrates the fluidity between material and non-material categories for NCP. For example, we found that picking flowers for shows can be regarded in the general categories from Díaz et al. (2018) as both material and non-material, since it contributes to supporting identities (Table 4). This result echoes previous findings that mushroom harvesting is both a material and non-material NCP (GarcíaNieto et al 2013). Of particular interest for further research would be in-depth assessment of perceptions of beneficial and detrimental renosterveld wildlife to unpick perceptions of different taxonomic groups and their specific functions (e.g. Morales-Reyes et al. 2018; Pascual Rico et al. 2020). Further quantifying relational values held by CFR land managers may also help to test the causation of certain NCP outcomes, and to support political legitimacy of conservation decision-making (Schulz and Martin-Ortega 2018), as well as effectively motivate landowner participation in conservation programs (Chapman et al. 2019). Additionally, scenario planning to further understand the constraints of these different contexts to changing land management would help to concretize these concepts further. These approaches could help to scale up pluralistic valuation of the CFR biodiversity hotspot in the future.

\section{Concluding remarks}

Our application of the vrk and NCP frameworks to renosterveld land management in the CFR identify three different land-use decision-making contexts. Bottom-up and Top-down conservation contexts contain relational values, but differing knowledge and rule types, while a Utility context is principally determined by instrumental values, formal rule types and technical knowledge. Remaining renosterveld fragments are associated with multiple NCP, demonstrating the contribution of these fragments to the multifunctional agricultural landscape, but material, non-material and regulating NCP types vary among the decision-making contexts. As important as understanding where these contexts diverge is recognizing their overlap, in order to foster decision-making for integrated renosterveld management. Hence, it is crucial to note that land managers express multiple and at times conflicting values, rules and knowledge and thereby occupy multiple decision-making contexts. Relational values are also key to understanding how land-managers perceive and therefore make decisions for renosterveld use. The success of integration of conservation and utility approaches dictates the survival of an irreplaceable ecosystem which, despite extensive fragmentation, continues to provide a diverse range of contributions to people.

Acknowledgements Our thanks go to Sarah Pendle, Katharina Talanow and Arnold van der Westhuizen for translation and transcription. We thank Annabelle Braasch for the design of icons. We are very grateful to all the land managers who participated in the study for their willingness and openness to support our research. The Robert-Bosch Foundation supports JL through a Junior Professorship for Research into Sustainable Use of Natural Resources. We also thank two anonymous reviewers who provided helpful comments and insights on previous versions of the manuscript. 
Author contributions ET: Conceptualization, Investigation, Writing-Original Draft Preparation. JL: Conceptualization, Supervision, Project administration, Funding Acquisition, Writing-Review \& Editing. BML: Conceptualization, Methodology, Supervision, Writing-Review \& Editing.

Funding Open Access funding enabled and organized by Projekt DEAL. This research was funded by the German Research Foundation (DFG, LO 2323/1-1), awarded to JL.

\section{Compliance with Ethical Standards}

Conflict of interest The authors declare that they have no conflict of interest.

Ethical approval We conducted our study with ethical clearance from the University of Göttingen Ethics Committee on 15.11.2017.
Open Access This article is licensed under a Creative Commons Attribution 4.0 International License, which permits use, sharing, adaptation, distribution and reproduction in any medium or format, as long as you give appropriate credit to the original author(s) and the source, provide a link to the Creative Commons licence, and indicate if changes were made. The images or other third party material in this article are included in the article's Creative Commons licence, unless indicated otherwise in a credit line to the material. If material is not included in the article's Creative Commons licence and your intended use is not permitted by statutory regulation or exceeds the permitted use, you will need to obtain permission directly from the copyright holder. To view a copy of this licence, visit http://creativecommons.org/licenses/by/4.0/.

\section{Appendix 1: Interviewee data}

See Table 5.

Table 5 Interviewee data

\begin{tabular}{|c|c|c|c|c|c|c|}
\hline Code & Gender & Age & Primary crop & Farm size (ha) & $\begin{array}{l}\text { Renosterveld frag- } \\
\text { ment } \operatorname{size}^{a} \text { (ha) }\end{array}$ & $\begin{array}{l}\text { Duration of } \\
\text { interview } \\
(\mathrm{min})\end{array}$ \\
\hline Wh1 & M & $30-50$ & Wheat & 163 & 51.2 & 41 \\
\hline Wh2 & M & $30-50$ & Wheat & 450 & 0.7 & 43 \\
\hline Wh3 & M & $30-50$ & Wheat & 380 & 9.8 & 26 \\
\hline Wh4 & M & $>50$ & Wheat & 1080 & 13.0 & 19 \\
\hline Wh5 & M & $>50$ & Wheat & 470 & 1036.5 & 50 \\
\hline Wh6 & M & $30-50$ & Wheat & 471 & 1.5 & 37 \\
\hline Wh7 & M & $>50$ & Wheat & 46 & 38.7 & 48 \\
\hline Wh8 & M & $30-50$ & Wheat & 1800 & 60.8 & 46 \\
\hline Wh9 & M & $30-50$ & Wheat & 1000 & 464.9 & 35 \\
\hline Wh10 & M & $30-50$ & Wheat & 450 & 112.8 & 38 \\
\hline Wh11 & M & $30-50$ & Wheat & 720 & 446.1 & 38 \\
\hline Wh12 & M & $>50$ & Wheat & 620 & 1.4 & 37 \\
\hline Wh13 & M & $<30$ & Wheat & 300 & 9.3 & 33 \\
\hline Wi1 & $\mathrm{F}$ & $30-50$ & Wine grape & 520 & 3.3 & 31 \\
\hline Wi2 & M & $30-50$ & Wine grape & 350 & 485.0 & 17 \\
\hline Wi3 & M & $>50$ & Wine grape & 550 & 9.2 & 42 \\
\hline Wi4 & M & $<30$ & Wine grape & 460 & 11.9 & 35 \\
\hline Wi5 & M & $30-50$ & Wine grape & 180 & 1401.1 & 25 \\
\hline Wi6 & M & $>50$ & Wine grape & 315 & 633.8 & 34 \\
\hline Wi7 & M & $>50$ & Wine grape & 483 & 9.0 & 23 \\
\hline Wi8 & M & $30-50$ & Wine grape & 729 & 27.0 & 31 \\
\hline Wi9 & M & $30-50$ & Wine grape & 560 & 96.3 & 45 \\
\hline Wi10 & M & $30-50$ & Wine grape & 1300 & 14.7 & 35 \\
\hline Wi11 & M & $30-50$ & Wine grape & 755 & 3.4 & 23 \\
\hline Wi12 & M & $>50$ & Wine grape & 1000 & 1.4 & 25 \\
\hline Wi13 & M & $30-50$ & Wine grape & 180 & 0.9 & 25 \\
\hline Wi14 & M & $30-50$ & Wine grape & 321 & 7.1 & 18 \\
\hline O1 & $\mathrm{F}$ & $>50$ & Other & NA & 22.6 & 50 \\
\hline $\mathrm{O} 2$ & $\mathrm{~F}$ & $30-50$ & Other & NA & 31.0 & 39 \\
\hline $\mathrm{O} 3$ & $\mathrm{~F}$ & $30-50$ & Other & NA & 17.8 & 29 \\
\hline
\end{tabular}

${ }^{a}$ Renosterveld fragment size refers to the entire size of the fragment, which could also border neighbouring farms, hence the size in ha can be larger than farm size. 


\section{Appendix 2: Ordination \\ of values-rules-knowledge (vrk)}

See Fig. 4.

See Table 6.

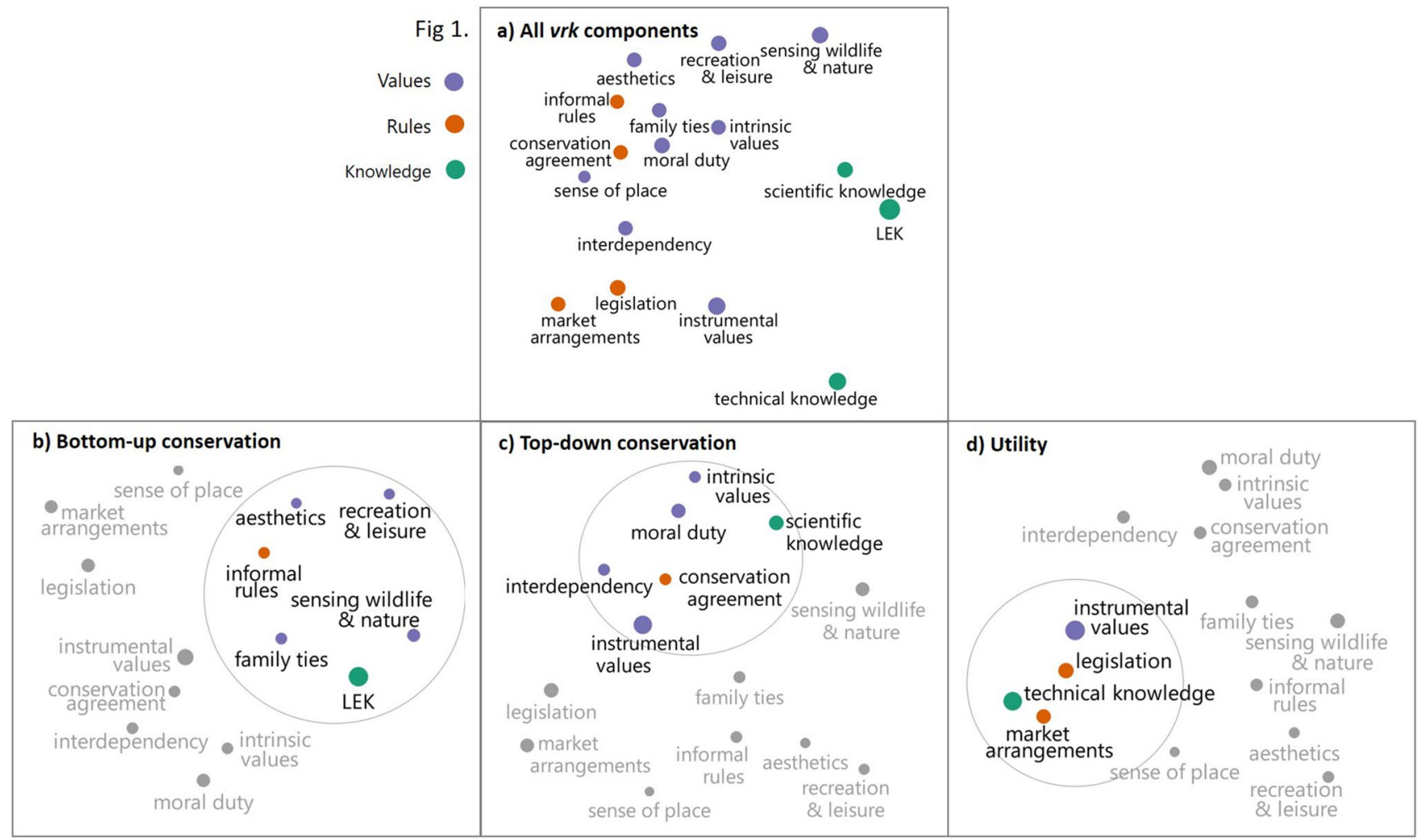

Fig. 4 Ordination of values-rules-knowledge (vrk) based on Principle Co-ordinates Analysis (PCoA), performed in MaxQDA 2020 (Verbi Software 2019) with the 'Code Maps' function. Closeness of points suggests associations among coded components. Size of point relates to number of code occurrences and ranges between 11 and 127. In (a), all vrk components including the three knowledge types are included. Knowledge types do not show clear dissimilarity, so we chose to separate the ordination by knowledge type. (b-d) Ordination for vrk separated by knowledge type. Vrk components which were most closely associated with each knowledge type are shown in colours according to the legend. Remaining vrk components are shown in light grey. These associations provide the basis for the different decision-making contexts 


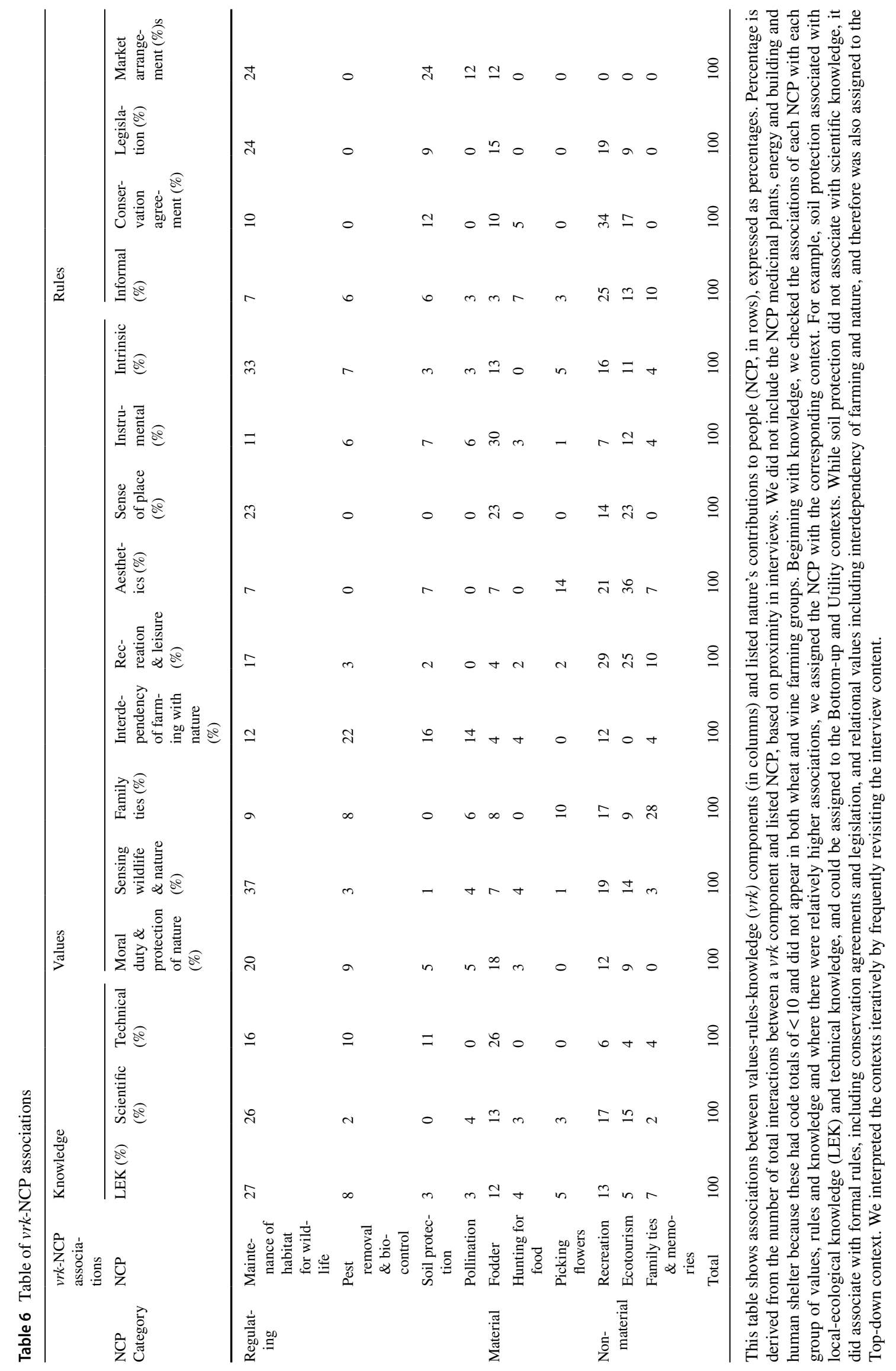




\section{References}

Abrams RW, Anwana ED, Ormsby A, Dovie DB, Ajagbe A, Abrams A (2009) Integrating top-down with bottom-up conservation policy in Africa. Cons Bio 23(4):799-804. https://doi.org/10.111 $1 / \mathrm{j} .1523-1739.2009 .01285 . \mathrm{x}$

Abson DJ, Fischer J, Leventon J, Newig J, Schomerus T, Vilsmaier $\mathrm{U}$, von Wehrden $\mathrm{H}$, Abernethy P, Ives CD, Jager NW, Lang DJ (2017) Leverage points for sustainability transformation. Ambio 46:30-39. https://doi.org/10.1007/s13280-016-0800-y

Allen KE, Quinn CE, English C, Quinn JE (2018) Relational values in agroecosystem governance. Curr Opin Environ Sustain 35:1-8. https://doi.org/10.1016/j.cosust.2018.10.026

Arias-Arévalo P, Gomez-Baggethun E, Martin-Lopez B, Perez-Rincon M (2018) Widening the evaluative space for ecosytem services: a taxonomy of plural values and valuation methods. Environ Values 27:29-53

Arias-Arévalo P, Martín-López B, Gómez-Baggethun E (2017) Exploring intrinsic, instrumental, and relational values for sustainable management of social-ecological systems. Ecol Soc 22(4):43. https://doi.org/10.5751/ES-09812-220443

Baker K, Eichhorn MP, Griffiths M (2019) Decolonizing field ecology. Biotropica 51:288-292. https://doi.org/10.1111/btp.12663

Bergh NG, Verboom A, Rouget M, Cowling RM (2014) Vegetation types of the Greater Cape Floristic Region. In: Allsop N, Colville JF, Verboom A (eds) Fynbos: ecology, evolution and conservation of a megadiverse region, 1st edn. Oxford University Press, Oxford, pp 1-25

Cash D, Clark C, Alcock F, Dickson NM, Eckley N, Guston DH, Jäger J, Mitchell RB (2003) Knowledge systems for sustainable development. Proc Nat Acad Sci 100(14):8086-8091

Chapman M, Satterfield T, Chan KMA (2019) When value conflicts are barriers: Can relational values help explain farmer participation in conservation incentive programs? Land Use Policy 82:464-475

Chan KMA, Balvanera P, Benessaiah K, Chapman M, Díaz S (2016) Why protect nature? Rethinking values and the environment. Proc Natl Acad Sci USA 113:1462-1465. https://doi.org/10.1073/ pnas. 1525002113

Clements HS, Kerley GIH, Cumming GS, de Vos A, Cook CN (2019) Privately protected areas provide key opportunities for the regional persistence of large- and medium-sized mammals. J Appl Ecol 56:537-546. https://doi.org/10.1111/1365-2664.13300

Colloff MJ, Gorrdard R, Dunlop M (2018) The values-rules-knowledge framework in adaptation decision making: a primer. CSIRO Land and Water, Canberra

Colloff MJ, Lavorel S, van Kerkhoff LE, Wyborn CA, Fazey I, Gorddard R, Mace GM, Foden WB, Dunlop M, Prentice IC, Crowley J, Leadley P, Degeorges P (2017a) Transforming conservation science and practice for a postnormal world. Conserv Biol 31:10081017. https://doi.org/10.1111/cobi.12912

Colloff MJ, Martín-López B, Lavorel S, Locatelli B, Gorddard R, Longaretti PY, Walters G, van Kerkoff L, Wyborn C, Coreau A, Wise RM, Dunlop M, Degeorges P, Grantham H, Overton IC, Williams RD, Doherty MD, Capon T, Sanderson T, Murphy HT (2017b) An integrative research framework for enabling transformative adaptation. Environ Sci Policy 68:87-96. https://doi.org/10.1016/j. envsci.2016.11.007

Conservation of Agricultural Resources Act 43 of 1983 (1983) Department of Agriculture, Pretoria, South Africa

Cornell S, Berkhout F, Tuinstra W, Tabara JD, Jaeger J, Chabay I, de Wit B, Langlais R, Mills D, Moll P, Otto IM, Petersen A, Pohl C, van Kerkhoff L (2013) Opening up knowledge systems for better responses to global environmental change. Environ Sci Policy 28:60-70. https://doi.org/10.1016/j.envsci.2012.11.008
Cowling RM (1983) A syntaxonomic and synecological study in the Humansdorp region of the Fynbos Biome. Bothalia 15:175-227

Cowling RM, Pressey RL, Rouget M, Lombard AT (2003) A conservation plan for a global biodiversity hotspot - the Cape Floristic Region, South Africa. Biol Conserv 112:191-216. https://doi. org/10.1016/S0006-3207(02)00425-1

Crane W (2006) Biodiversity conservation and land rights in South Africa: Whither the farm dwellers? Geoforum 37:1035-1045. https://doi.org/10.1016/j.geoforum.2006.07.002

Darnhofer I, Schneeberger W, Freyer B (2005) Converting or not converting to organic farming in Austria: Farmer types and their rationale. Agric Hum Values 22(1):39-52

De Vos A, Cumming GS (2019) The contribution of land tenure diversity to the spatial resilience of protected area networks. People Nat 1:331-346. https://doi.org/10.1002/pan3.29

Díaz S, Demissew S, Carabias J, Joly C, Lonsdale M, Ash N, Larigauderie A, Adhikari JR, Arico S, Baldi A, Bartuska A et al (2015) The IPBES Conceptual Framework-connecting nature and people. Curr Opin Environ Sustain 14:1-16. https://doi.org/10.1016/j. cosust.2014.11.002

Díaz S, Pascual U, Stenseke M, Martín-López B, Watson RT, Molnár Z, Hill R, Chan KMA, Baste IA, Brauman KA, Polasky S et al (2018) Assessing nature's contributions to people: recognizing culture, and diverse sources of knowledge, can improve assessments. Science 359:270-272. https://doi.org/10.1126/scien ce.aap 8826

Díaz S, Settele J, Brondizio E, Ngo HT, Agard J, Arneth A, Balvanera P, Brauman KA, Butchart HM, Chan KMA, Garibaldi LA, Ichii K, Liu J, Subramanian SM, Midgeley GF, Miloslavich P, Molnar Z, Obura D, Pfaff A, Polasky S, Purvis S, Razzaque J, Reyers B, Chowdhury RR, Shin YJ, Visseren-Hamakers I, Willis KJ, Zayas CN (2019) Pervasive human-driven decline of life on Earth points to the need for transformative change. Science 366(6741):1-10. https://doi.org/10.1126/science.aax3100

Dietz T, Ostrom E, Stern PC (2008) The struggle to govern the commons. Urban Ecol An Int Perspect Interact Between Humans Nat 302:611-622. https://doi.org/10.1007/978-0-387-73412-5_40

Ellis EC, Pascual U, Mertz O (2019) Ecosystem services and nature's contribution to people: negotiating diverse values and trade-offs in land systems. Curr Opin Environ Sustain 38:86-94. https://doi. org/10.1016/j.cosust.2019.05.001

Emerson K, Gerlak AK (2014) Adaptation in collaborative governance regimes. Environ Manag 54:768-781. https://doi.org/10.1007/ s00267-014-0334-7

Enqvist JP, Tengö M, Bodin Ö (2019) Are bottom-up approaches good for promoting social-ecological fit in urban landscapes? Ambio 49:49-61. https://doi.org/10.1007/s13280-019-01163-4

García-Nieto AP, García-Llorente M, Iniesta-Arandia I, Martín-López B (2013) Mapping forest ecosystem services: From providing units to beneficiaries. Ecosyst Serv 4:126-138. https://doi. org/10.1016/j.ecoser.2013.03.003

Giliomee JH (2006) Conserving and increasing biodiversity in the large-scale, intensive farming systems of the Western Cape, South Africa. S Afr J Sci 102:375-378

Gorddard R, Colloff MJ, Wise RM, Ware D, Dunlop M (2016) Values, rules and knowledge: adaptation as change in the decision context. Environ Sci Policy 57:60-69. https://doi.org/10.1016/j. envsci.2015.12.004

Gosling E, Williams KJH (2010) Connectedness to nature, place attachment and conservation behaviour : Testing connectedness theory among farmers. J Environ Psychol 30:298-304. https://doi. org/10.1016/j.jenvp.2010.01.005

Halpern ABW, Meadows ME (2013) Fifty years of land use change in the Swartland, Western Cape, South Africa: characteristics, causes and consequences. South African Geogr J 95:38-49. https://doi. org/10.1080/03736245.2013.806101 
Hill R, Nates-Parra G, Quezada-Euán JJG, Buchori D, LeBuhn G, Maués MM, Pert PL, Kwapong PK, Saeed S, Breslow SJ, da Cunha MC et al (2019) Biocultural approaches to pollinator conservation. Nat Sustain 2:214-222. https://doi.org/10.1038/s4189 3-019-0244-Z

Himes A, Muraca B (2018) Relational values : the key to pluralistic valuation of ecosystem services. Curr Opin Environ Sustain 35:1-7. https://doi.org/10.1016/j.cosust.2018.09.005

Hornby D, Nel A, Chademana S, Khanyile N (2018) A slipping hold? Farm dweller precarity in South Africa's changing agrarian economy and climate. Land 7(2):1-25. https://doi.org/10.3390/land7 020040

Iniesta-Arandia I, García-Llorente M, Aguilera PA, Montes C, Martín-López B (2014) Socio-cultural valuation of ecosystem services: uncovering the links between values, drivers of change, and human well-being. Ecol Econ 108:36-48. https://doi. org/10.1016/j.ecolecon.2014.09.028

IPBES (2018) Summary for policymakers of the regional assessment report on biodiversity and ecosystem services for Europe and Central Asia. In: Fischer M, Rounsevell M, Torre-Marin A, Mader A, Church A, Elbakidze M, Elias V, Hahn T, Harrison PA, Hauck J, Martín-López B et al (eds) IPBES Secretariat, Bonn, Germany

IPBES (2019) Summary for policymakers of the global assessment report on biodiversity and ecosystem services of the Intergovernmental Science-Policy Platform on Biodiversity and Ecosystem Services. In: Diaz S, Settele J, Brondizio ES, Ngo HT, Gueze M, Agard J, Arneth A, Balvanera P, Brauman KA, Butchart SHM, Chan KMA et al (eds), IPBES Secretariat, Bonn, Germany.

Ives CD, Abson DJ, von Wehrden H, Dorninger C, Klaniecki K, Fischer J (2018) Reconnecting with nature for sustainability. Sustain Sci. https://doi.org/10.1007/s11625-018-0542-9

Jacobs S, Martín-López B, Barton DN, Dunford R, Harrison PA, Kelemen E, Saarikoski H, Termansen M, García-Llorente M, GómezBaggathun E, Kopperoinen L et al (2018) The means determine the end-pursuing integrated valuation in practice. Ecosyst Serv 29:515-528. https://doi.org/10.1016/j.ecoser.2017.07.011

Jax K, Calestani M, Chan KMA, Eser U, Keune H, Muraca B, O’Brien L, Potthast T, Voget-Kleschin L, Wittmer H (2018) Caring for nature matters: a relational approach for understanding nature's contributions to human well-being. Curr Opin Environ Sustain 35:22-29. https://doi.org/10.1016/j.cosust.2018.10.009

Kemper J, Cowling RM, Richardson DM (1999) Fragmentation of South African renosterveld shrublands: effects on plant community structure and conservation implications. Biol Conserv 90:103-111. https://doi.org/10.1016/S0006-3207(99)00021-X

Keniger LE, Gaston KJ, Irvine KN, Fuller RA (2013) What are the Benefits of Interacting with Nature ? Int J Environ Res Public Health 10:913-935. https://doi.org/10.3390/ijerph10030913

Kenward RE, Whittingham MJ, Arampatzis S, Manos BD, Hahn T, Terry A, Simoncini R, Alcorn J, Bastian O, Donlan M, Elowe K et al (2011) Identifying governance strategies that effectively support ecosystem services, resource sustainability, and biodiversity. Proc Nat Acad Sci 108(13):5308-5312

Klain SC, Satterfield TA, Chan KMA (2014) What matters and why? Ecosystem services and their bundled qualities. Ecol Econ 107:310-320

Lochner P, Weaver A, Gelderblom C, Peart R, Sandwith T, Fowkes S (2003) Aligning the diverse: the development of a biodiversity conservation strategy for the Cape Floristic Region. Biol Conserv 112(1-2):29-43

Martín-López B, Iniesta-Arandia I, García-Llorente M, Palomo I, Casado-Arzuaga I, Del Amo DG, Gómez-Baggathun E, OterosRozas E, Placios-Agundez I, Willaarts B, Gonzáles JA et al (2012) Uncovering ecosystem service bundles through social preferences. PLoS ONE 7(6):1-11. https://doi.org/10.1371/journal.pone.00389 70
Martín-López B, Montes C (2015) Restoring the human capacity for conserving biodiversity: a social-ecological approach. Sustain Sci 10:699-706. https://doi.org/10.1007/s11625-014-0283-3

Masterson VA, Stedman RC, Enqvist J, Tengö M, Giusti M, Wahl D, Svedin U (2017) The contribution of sense of place to socialecological systems research: A review and research agenda. Ecol Soc. https://doi.org/10.5751/ES-08872-220149

Mastrangelo M, Pérez-harguindeguy N, Enrico L, Bennett E, Lavorel S, Cumming GS, Abeygunawardane D, Amarilla LD, Burkhard B, Egoh BN, Frishkoff L et al (2019) Key knowledge gaps to achieve global sustainability goals. Nat Sustain 2:1115-1121. https://doi. org/10.1038/s41893-019-0412-1

McDowell C, Moll E (1992) The influence of agriculture on the decline of west-coast renosterveld, South-western Cape, South Africa. J Environ Manage 35:173-192. https://doi.org/10.1016/S0301 $-4797(05) 80118-5$

Millennium Ecosystem Assessment (2005) Ecosystems and human wellbeing (Program). Island Press, Washington DC

Morales-Reyes Z, Martín-López B, Moleón M, Mateo-Tomás P, Olea PP, Arrondo E, Donázar JA, Sánchez-Zapata JA (2019) Shepherds' local knowledge and scientific data on the scavenging ecosystem service : insights for conservation. Ambio 48:48-60. https ://doi.org/10.1007/s13280-018-1055-6

Moll EJ, Bossi L (1984) Assessment of the extent of the natural vegetation of the fynbos biome of South Africa. S Afr J Sci 80:355-358

Morales-Reyes Z, Martín-López B, Moleón M, Mateo-Tomás P, Botella F, Margalida A, Donázar JA, Blanco G, Pérez I, Sánchez-Zapata JA (2018) Farmer Perceptions of the Ecosystem Services Provided by Scavengers : What, Who, and to Whom. Conserv Lett 11(2):1-11. https://doi.org/10.1111/conl.12392

Musil CF, Milton SJ, Davis GW (2005) The threat of alien invasive grasses to lowland Cape floral diversity: an empirical appraisal of the effectiveness of practical control strategies. S Afr J Sci 101:337-344

Myers N, Mittermeier RA, Mittermeier CG, da Fonseca GAB, Kent J (2000) Biodiversity hotspots for conservation priorities. Nature 403(6772):853-858. https://doi.org/10.1038/35002501

National Environmental Management: Biodiversity Act 10 of 2004 (2013) Department of Agriculture, Pretoria, South Africa

Newton IP, Knight RS (2005) The use of Landsat imagery for the identification of the remaining West Coast Renosterveld fragments, Western Cape Province, South Africa. South Afr J Bot 71:67-75

O’Connor S, Kenter JO (2019) Making intrinsic values work; integrating intrinsic values of the more-than-human world through the Life Framework of Values. Sustain Sci 14:1247-1265. https://doi. org/10.1007/s11625-019-00715-7

O'Farrell PJ, Donaldson JS, Hoffman MT (2009) Local benefits of retaining natural vegetation for soil retention and hydrological services. South Afr J Bot 75:573-583. https://doi.org/10.1016/j. sajb.2009.06.008

Olson DM, Dinerstein E (2002) The Global 200: Priority Ecoregions for Global Conservation. Ann Missouri Bot Gard 89:199-224

Ostrom E (2009) A general framework for analysing sustainability of social-ecological systems. Science 325:419-422

Pascual U, Balvanera P, Díaz S, Pataki G, Roth E, Stenseke M, Watson RT, Dessane AB, Islar M, Kelemen E, Maris V et al (2017) Valuing nature's contributions to people: the IPBES approach. Curr Opin Environ Sustain 26-27:7-16. https://doi.org/10.1016/j.cosus t.2016.12.006

Pascual Rico R, Martín-López B, Sánchez-Zapata JA, MoralesReyes Z (2020) Scientific priorities and shepherds' perceptions of ungulate's contributions to people in rewilding landscapes. Sci Total Environ 705:135876. https://doi.org/10.1016/j.scito tenv.2019.135876

Paavola J (2007) Institutions and environmental governance: a reconceptualization. Ecol Econ 63(1):93-103 
Pereira HM, Navarro LM, Martins IS (2012) Global biodiversity change: the bad, the good, and the unknown. Annu Rev Environ Resour 37:25-50. https://doi.org/10.1146/annurev-environ-04291 $1-093511$

Prober SM, Colloff MJ, Abel N, Crimp S, Doherty MD, Dunlop M, Eldridge DJ, Gorddard R, Lavorel S, Metcalfe DJ, Murphy HT et al (2017) Informing climate adaptation pathways in multi-use woodland landscapes using the values-rules-knowledge framework. Agric Ecosyst Environ 241:39-53. https://doi.org/10.1016/j. agee.2017.02.021

Pelling M (2011) Adaptation to climate change: from resilience to transformation. Routledge, London

Rouget M, Barnett M, Cowling RM, Cumming T, Daniels F, Hoffman MT, Manuel J (2014) Conserving the Cape Floristic Region. In: Allsop N, Colville JF, Verboom G (eds) Fynbos: ecology, evolution and conservation of a Megadiverse Region. Oxford University Press, Oxford, pp 321-336

Saunders ME, Luck GW (2016) Limitations of the ecosystem services versus disservices dichotomy. Conserv Biol 30:1363-1365. https ://doi.org/10.1111/cobi.12740

Saunders ME, Peisley RK, Rader R, Luck GW (2016) Pollinators, pests, and predators: recognizing ecological trade-offs in agroecosystems. Ambio 45:4-14. https://doi.org/10.1007/s 1328 0-015-0696-y

Schulz C, Martin-Ortega J (2018) Quantifying relational valueswhy not? Curr Opin Environ Sustain 35:15-21. https://doi. org/10.1016/j.cosust.2018.10.015

Soga M, Gaston KJ (2016) Extinction of experience: the loss of human-nature interactions. Front Ecol Environ 14:94-101. https ://doi.org/10.1002/fee.1225

Sukhdev P, Wittmer H, Schroeter-Schlaack C, Nesshöver C, Bishop J, ten Brink P, Gundimeda H, Kumar P, Simmons B (2010) The economics of ecosystems and biodiversity: mainstreaming the economics of nature: a synthesis of the approach, conclusions and recommendations of TEEB. Progress Press, Malta

Tadaki M, Sinner J, Chan KMA (2017) Making sense of environmental values: A typology of concepts. Ecol Soc. https://doi.org/10.5751/ ES-08999-220107

Tengö M, Brondizio ES, Elmqvist T, Malmer P, Spierenburg M (2014) Connecting diverse knowledge systems for enhanced ecosystem governance: the multiple evidence base approach. Ambio 43(5):579-591. https://doi.org/10.1007/s13280-014-0501-3

Tengö M, Hill R, Malmer P, Raymond CM, Spierenburg M, Danielsen F, Elmqvist T, Folke C (2017) Weaving knowledge systems in
IPBES, CBD and beyond-lessons learned for sustainability. Curr Opin Environ Sustain 26-27:17-25. https://doi.org/10.1016/j. cosust.2016.12.005

Topp EN, Loos J (2019) Fragmented landscape, fragmented knowledge : a synthesis of renosterveld ecology and conservation. Environ Conserv 46:171-179. https://doi.org/10.1017/S0376 892918000498

VERBI Software (2019) MAXQDA 2020 [computer software]. Berlin, Germany: VERBI Software. Available from maxqda.com

Von Hase A, Rouget M, Maze K, Helme N (2003) A fine-scale conservation plan for Cape lowlands renosterveld: technical report. In: Rep Cape Conservation Unit 2, Botanical Society of South Africa: $1-104$

Von Hase A, Rouget M, Cowling RM (2010) Evaluating private land conservation in the cape lowlands, South Africa. Conserv Biol 24:1182-1189. https://doi.org/10.1111/j.1523-1739.2010.01561.x

West S, Haider LJ, Masterson V, Enqvist JP, Svedin U, Tengö M (2018) Stewardship, care and relational values. Curr Opin Environ Sustain 35:30-38. https://doi.org/10.1016/j.cosust.2018.10.008

Western Cape Government (2017) Swartland municipality socio-economic profile. Malmesbury, Western Cape

Western Cape Department of Agriculture AgriStats (2019) Municipal Statistics Crop Census Layer, http://www.elsenburg.com/gis/apps/ agristats/. Accessed 08 Oct 2019

Winter SJ, Esler KJ, Kidd M (2005) An index to measure the conservation attitudes of landowners towards Overberg Coastal Renosterveld, a critically endangered vegetation type in the Cape Floral Kingdom, South Africa. Biol Conserv 126:383-394. https://doi. org/10.1016/j.biocon.2005.06.015

Winter SJ, Prozesky H, Esler KJ (2007) A case study of landholder attitudes and behaviour toward the conservation of renosterveld, a critically endangered vegetation type in Cape Floral Kingdom, South Africa. Environ Manag 40:46-61. https://doi.org/10.1007/ s00267-006-0086-0

Wise RM, Fazey I, Stafford Smith M, Park SE, Eakin HC, Archer van Garderen ARM, Campbell B (2014) Reconceptualising adaptation to climate change as part of pathways of change and response. Glob Environ Chang 28:325-336. https://doi.org/10.1016/j.gloen vcha.2013.12.002

Publisher's Note Springer Nature remains neutral with regard to jurisdictional claims in published maps and institutional affiliations. 